\title{
The Lender of Last Resort Function after the Global Financial Crisis
}




\section{WP/16/10}

\section{IMF Working Paper}

\section{The Lender of Last Resort Function after the Global Financial Crisis}

by Marc Dobler, Simon Gray, Diarmuid Murphy, and

Bozena Radzewicz-Bak

IMF Working Papers describe research in progress by the author(s) and are published to elicit comments and to encourage debate. The views expressed in IMF Working Papers are those of the author(s) and do not necessarily represent the views of the IMF, its Executive Board, or IMF management.

I N T E R N A T I O N A L M O N E T A R Y F U N D 


\title{
IMF Working Paper
}

Monetary and Capital Markets Department

The Lender of Last Resort Function after the Global Financial Crisis

Prepared by Marc Dobler, Simon Gray, Diarmuid Murphy, and Bozena Radzewicz-Bak ${ }^{1}$

\section{Authorized for distribution by Ghiath Shabsigh}

January 2016

\section{IMF Working Papers describe research in progress by the author(s) and are published to} elicit comments and to encourage debate. The views expressed in IMF Working Papers are those of the author(s) and do not necessarily represent the views of the IMF, its Executive Board, or IMF management.

\begin{abstract}
The global financial crisis (GFC) has renewed interest in emergency liquidity support (sometimes referred to as "Lender of Last Resort") provided by central banks to financial institutions and challenged the traditional way of conducting these operations. Despite a vast literature on the topic, central bank approaches and practices vary considerably. In this paper we focus on, for the most part, the provision of idiosyncratic support, approaching it from an operational perspective; highlighting different approaches adopted by central banks; and also identifying some of the issues that arose during the GFC.

JEL Classification Numbers: E58, G21, G28

Keywords: lender of last resort, collateral, risk control measures

Authors’ E-Mail Addresses: mdobler@,imf.org; sgray@imf.org; dmurphy@imf.org; and bradzewiczbak@imf.org.

\footnotetext{
${ }^{1}$ The authors wish to thank Dong He, Alvaro Piris Chavarri, Kristine Drevina, Kelly Eckhold, Darryl King, Peter Lohmus, Erlend Nier, Miguel Savastano, and Froukelien Wendt, for their useful comments. A special thanks also to a number of central bank colleagues who offered advice and comments on an earlier draft of this working paper. Remaining errors are the authors' responsibility.
} 


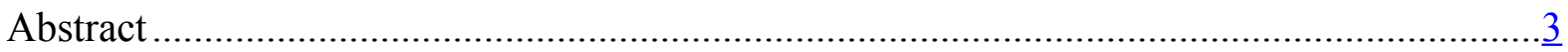

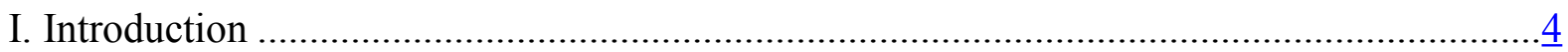

II. Central Bank Liquidity Provision—Stressed Times ...........................................................

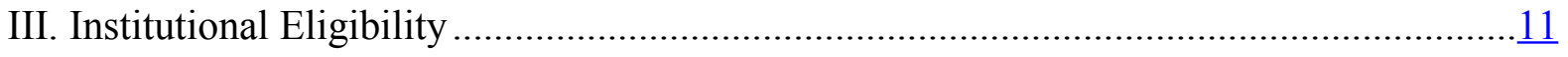

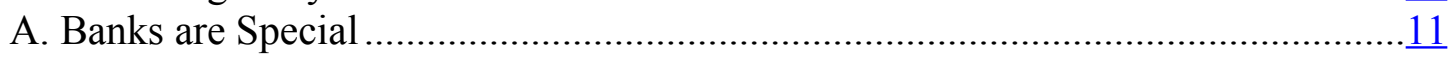

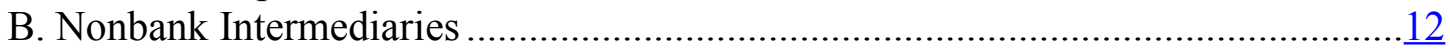

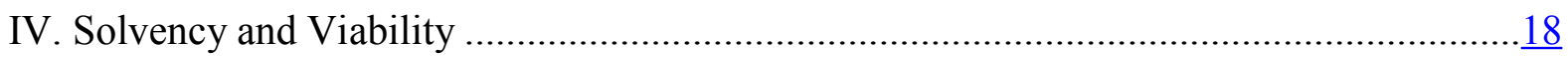

A. Not Just a "Point-in-Time"Assessment...........................................................18

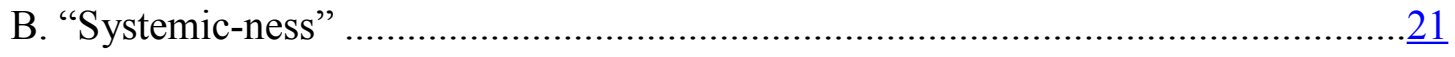

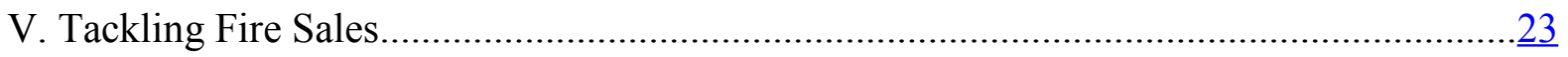

A. Recourse versus Non-recourse Lending ……………………………………....24

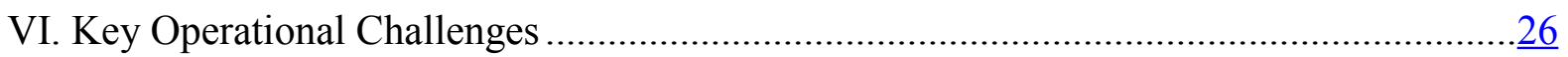

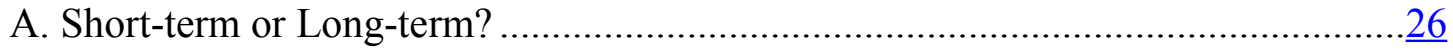

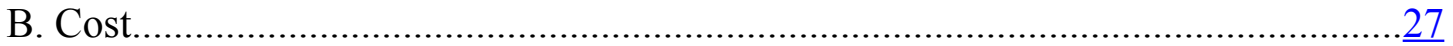

C. Adequate Collateral .........................................................................................

D. Supervisory Response - Domestic Institutions....................................................

E. Supervisory Response - Cross-Border Banks.......................................................

F. Foreign Currency Lender of Last Resort ..................................................................

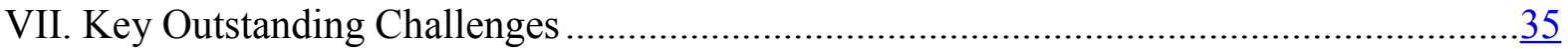

A. Central Bank Autonomy …………………………………………………...

B. Competition Policy ………………………………………………………....

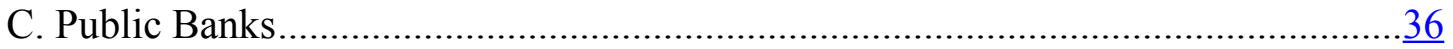

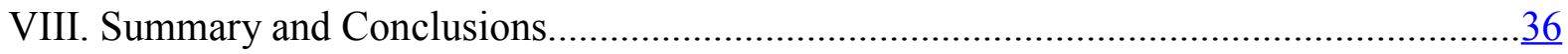

A. Interaction with the Market............................................................................41

B. Stakeholder Coordination...................................................................................4

\section{Tables}

1. Central Bank Response to Liquidity Problems ..............................................................

2. Disclosure: "Rules-based" Versus Ambiguity ……………...........................................

3. An Example of Stakeholder Coordination ....................................................................

4. Examples of Lender of Last Resort Collateral.............................................................

5. Central Bank Valuation Approaches …………………................................................

\section{Boxes}

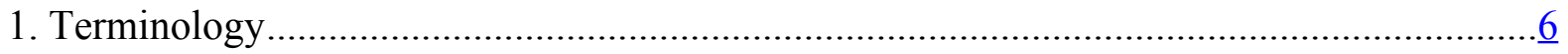

2. Committed Liquidity Facilities: Where Do They Fit? ...........................................................

3. Growing Importance of Lender of Last Resort for Central Clearing Counterparties ............18 


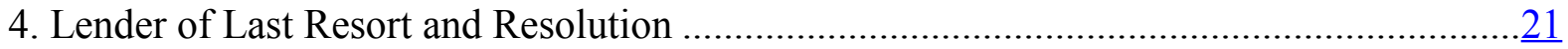

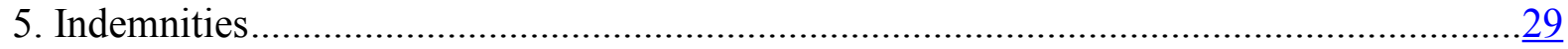

6. Examples of Funding Alternatives to Lender of Last Resort ..............................................47

\section{Appendices}

I. Overview of Major Central Bank Systemic and Idiosyncratic Responses to the Global

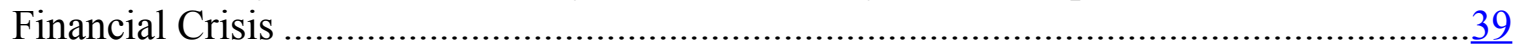

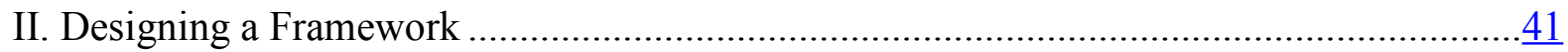

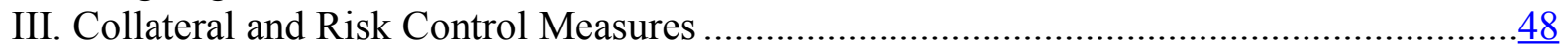

III. Minimizing Stigma - The Case of Open Market Operations ……………………...........

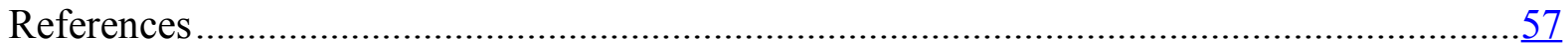




\section{INTRODUCTION}

There are a number of circumstances in which a central bank may wish or need to provide reserve money (and other forms of liquidity) to the banking system. Central banks (CBs) provide reserve money to their financial markets through open market operations (OMOs) as part of monetary policy implementation if the market has an ex ante shortage of reserve money; or to facilitate functioning of the payment system e.g., intra-day loans or a credit standing facility (SF). ${ }^{2} \mathrm{CBs}$ can also respond to the increased aggregate demand for reserve money, foreign exchange (FX), or liquid assets, resulting from a market shock when normal market functioning is disrupted; or to the idiosyncratic needs of one bank or a small group of banks. In this Working Paper we focus on the last of these, bilateral/idiosyncratic lender of last resort (LOLR) support, which is at the discretion of the $\mathrm{CB}$ and is provided in order to avoid spillover disturbances to the stability of the financial system. In addition, we explore approaches to managing the risks associated with asset fire sales by an individual or a few institutions.

The GFC of 2008-09 has revived interest in the design and operational modalities of LOLR support provided by CBs. The widely-held view, since it was espoused by Walter Bagehot ${ }^{3}$ in the nineteenth century, was that CBs should lend freely and at a high interest rate against good collateral (as considered during normal times), where the assumption was that a bank without good collateral was insolvent. In practice, CBs responded to liquidity shocks during the recent global crisis in a variety of ways - in some cases beyond their normal framework - to support financial stability. ${ }^{4}$ These circumstances challenged some of the traditional ways of conducting liquidity support, while also highlighting its importance in helping to contain financial distress.

This paper examines how the LOLR responses of CBs have evolved in recent times. Following a discussion of the distinction between idiosyncratic and systemic support, and the terminology used (Section II); the issues discussed are grouped under three broad areas:

- Institutional eligibility and the key considerations necessary before LOLR should be advanced, in particular to non-banks (Sections III and IV), a sector that is rapidly growing in significance in many countries;

\footnotetext{
${ }^{2}$ OMOs are undertaken at the initiative of the CB, while SFs are automatic and provided at the initiative of individual banks. See Gray and Talbot (2006) for a longer discussion of this point.

${ }^{3}$ Bagehot (1873).

${ }^{4}$ Some of the 'non-traditional' approaches mirrored schemes used by some emerging market countries in previous years.
} 
- A possible approach to tackling the risk of fire-sale of assets, when there is a shock to an asset market (Section V); and

- The key operational challenges a $\mathrm{CB}$ is likely to face-such as the appropriate length of support, how best to meet FX needs, and the identification of so-called "good" collateral - when implementing its LOLR framework, along with some of the operational issues that may remain a challenge for CBs going forward (Sections VI and VII).

The paper does not cover all aspects of LOLR. While it touches on the issues of moral hazard, the appropriate lending rate, and resolution (living wills, too-big-to-fail), it leaves other aspects such as recovery and the role of fiscal support measures, to a later paper.

\section{Central Bank Liquidity Provision-Stressed Times}

CBs can respond in a number of ways when there is an extraordinary shock to an individual bank or to the system as a whole. When normal market functioning is disrupted, CBs may need to respond to idiosyncratic needs (one bank or a few banks become illiquid) or systemic needs (there is a market-wide shock). But unlike standing facilities, the CB's response to idiosyncratic need is discretionary; and unlike both $\mathrm{OMO}$ and standing facilities, the nature of the need should trigger heightened regulatory oversight. ${ }^{5}$ In the case of an idiosyncratic shock, there may be no general need for additional reserve money, but credit risk concerns or market fragmentation may leave an individual bank short of liquidity. ${ }^{6}$ By contrast, in the case of a systemic shock, where demand for reserve money increases, only the $\mathrm{CB}$ can meet the need, since in a closed system of reserves supply, the CB is the only "port of call" for banks needing extra reserves.

Depending on the nature of the shock, the demand may, at times, be for reliably liquid assets rather than for reserve money per se. ${ }^{7}$ Liquid securities (notably, treasury securities) that can be used as collateral in market transactions may meet the demand as effectively as reserve money. Similarly, the demand may be for term funding (i.e., longer term liabilities) rather than more of a liquid asset, or for FX.

\footnotetext{
${ }^{5}$ While a system-wide need for liquidity support may indicate the need for heightened supervisory attention, this will be of a different nature to heightened scrutiny in response to idiosyncratic needs.

${ }^{6}$ For example, when Northern Rock in the United Kingdom (U.K.) was unable to roll over market funding in September 2007, the provision of LOLR funding had to be offset by a reduction in normal OMO lending, to avoid leaving the market with an overall excess of reserve money balances.

${ }^{7}$ Liquid assets may comprise (i) reserve money, possibly provided at a longer term maturity than normally available; (ii) FX; or (iii) liquid securities.
} 
This paper uses the term "idiosyncratic" to refer to lending to one or a small group of banks outside normal monetary policy operations; and 'systemic' to refer to generally available operations that extend the normal structure of monetary operations, when the market as a whole is stressed (Box 1). It focuses on idiosyncratic lending: the bilateral provision of liquidity_predominantly CB reserve money_at the CB's discretion, in reaction to an adverse shock which causes abnormal liquidity pressures on one or a small group of institutions.

\section{Box 1. Terminology}

CBs and the literature use different terms when describing CB lending beyond their standard monetary policy framework. The terms "LOLR," "Emergency Liquidity Assistance" (ELA), and "Exceptional Liquidity Assistance" are commonly used. These terms are sometimes used interchangeably but at other times have specific meanings based on whether the CB's response is bilateral or multilateral.

There appears to be particular confusion around the use of the terms LOLR and Emergency Liquidity Assistance. Some CBs use the term LOLR to describe discretionary lending to address an idiosyncratic problem (temporary strains mainly in individual banks or a group of similar banks). While some also use the term Emergency Liquidity Assistance to describe this, for others the term ELA relates solely to the provision of liquidity in response to a systemic need. (A CB's regular standing credit facility - part of its regular monetary operations framework - is not included here as a LOLR instrument: the SF is typically for overnight use only, and is non-discretionary.)

The use of the term Exceptional Liquidity Assistance appears to be more defined. The word "exceptional" rather than "emergency" is used by some CBs when, for example, the liquidity-stressed banks may require prolonged assistance and not just temporary support. Exceptional liquidity assistance could respond to an idiosyncratic or to a systemic need. Both Emergency and Exceptional Liquidity Assistance are sometimes included with so called "unconventional" monetary policy measures.

\section{Bilateral lender of last resort}

Bilateral LOLR is needed when an individual financial institution or a few of them are unable to maintain or roll over their funding, whether retail or wholesale. ${ }^{8}$ The demand for liquidity may stem from a single institution encountering immediate problems (such as deposit outflows or inability to roll over wholesale funding); or possibly a group of similar institutions - perhaps banks with similar business models or geographical focus - if the market doubts their longer-term viability. In the case of an individual or a small number of banks, any LOLR support will be provided at the CB's discretion, ${ }^{9}$ on a bilateral basis and at a penalty rate, and should trigger enhanced regulatory oversight.

\footnotetext{
${ }^{8}$ A run may be more likely on wholesale rather than retail funding where credible deposit insurance is in place.

${ }^{9}$ Some CBs offer a hybrid between a standing credit facility and LOLR in these circumstances, but this is not sound practice.
} 
The underlying rationale behind a CB's response is to prevent a disruption to financial stability. The provision of this liquidity support is generally performed under the CB's financial stability mandate. Fiscal authorities can provide alternative solutions (repos, deposits, asset purchases and swaps, or guarantees ${ }^{10}$ ) but rarely have immediate access to sufficiently large reserve money balances: "CBs have short-run deep pockets, while fiscal authorities have long-run deep pockets."

CBs should have discretion in deciding whether or not to meet the emergency liquidity needs of individual institutions. The provision of liquidity in response to an idiosyncratic need should only be contemplated when other funding solutions have first been fully explored and after due consideration has been given as to why this liquidity is being provided and in what format, in order to achieve desired goals. But this may have to happen very fast - possibly within a day.

The element of CB discretionary action is an important part of minimizing moral hazard. ${ }^{11}$ Moral hazard arises when "...central bank actions reduce the incentive for financial entities to protect themselves against risky outcomes", with a concern being that "... banks would improperly manage their funding risk, assuming that the CB would provide liquidity support in times of stress" (Lavoie et al., 2011). ${ }^{12}$ The willingness of financial institutions and their management to take on excessive liquidity risk can be reduced by uncertainty about whether the $\mathrm{CB}$ will provide support, by the imposition of punitive financial and non-financial penalties on management and shareholders and by strictly enforced frameworks for enhanced regulatory oversight and prompt corrective action. ${ }^{13}$

A key requirement of a CB's bilateral response is the imposition of supervisory intrusion and conditionality. Institutions in receipt of bilateral LOLR should be subject to enhanced supervision and conditionality so that the CB has comfort that LOLR can be repaid and that

\footnotetext{
${ }^{10}$ Asset swaps (government bonds provided in exchange for illiquid assets) may be available, taking advantage of the government's ability to issue debt securities quickly. In some countries, parliamentary approval may be needed, for example if issuance of additional debt securities or the provision of a government guarantee has to be accommodated in that year's budget.

${ }^{11}$ See Bindseil (2014) for a longer discussion on the topic of CB liquidity provision and moral hazard.

${ }^{12}$ Examples would include attracting short-term deposits or wholesale funding rather than paying up for longer term funding, assuming that the CB will meet any non-rollover of this short-term funding; or lending (even unsecured) to risky entities, knowing that if the funds are not returned, the CB will step in to meet the liquidity shortfall. This may be equivalent to parking illegally, on the assumption that over time it is cheaper and easier to pay an occasional fine, than to pay regularly for legal parking.

13 The U.S. Dodd-Frank Act (2010) deliberately restricts the ability of the Fed to provide idiosyncratic support to financial institutions, weakening any perception of an automatic bail-out.
} 
the public funding is being used for appropriate purposes. ${ }^{14}$ Good practice is for CBs to request funding plans from the institution in order to detect any deterioration in the situation early on, and apply policy actions accordingly. In particular, a viable path to a normal funding mix without a need for LOLR funding should be foreseeable in the plan. The nature of the problem may also prompt other requirements. For instance, a bank which has hit difficulties due to fraudulent loans to connected parties should not receive CB liquidity support while weak governance persists.

In response to a shortage of high quality liquid assets in their domestic markets, some CBs introduced committed liquidity lines that count towards a bank's regulatory liquidity requirements; but these are different to the concept of idiosyncratic LOLR (see Box 2) — not least because they are committed, rather than being subject to the discretion of the CB.

\section{Systemic lender of last resort at the central bank's initiative}

In the case of a market-wide shock, the banking system as a whole may face an increased demand for reserves. In such a situation, the CB is more likely to provide reserves on a multilateral basis through an auction-type mechanism. A CB's systemic emergency response, in consequence, is essentially an adjunct to liquidity management via OMOs. Liquidity is provided at the initiative of the $\mathrm{CB}$ in response to an increase in demand. It may not necessarily imply any change in the monetary policy stance; but it may help to deal with an impaired monetary policy transmission mechanism. ${ }^{15,16}$

Lending in response to systemic need may require a change in the terms on which OMOs are provided, such as lengthening the tenure and expanding the collateral accepted. This may even necessitate the creation of new facilities, as CBs focus on specific market issues e.g., an impaired monetary policy transmission mechanism, due to issues of fragmentation.

OMOs can allow the CB's market counterparties to direct liquidity to those participants most in need, while at the same time not causing distortions in the price mechanism. ${ }^{17}$ However, this is based on the assumption that the market counterparties are willing and able to on-lend

\footnotetext{
${ }^{14}$ Given this supervisory intrusion and conditionality, LOLR should not be used in order to comply with regulatory ratios.

${ }^{15}$ A systemic action would be a short-term response to a market shock; in contrast a change in monetary policy stance is normally the outcome of a pre-established calendar of meetings of the CB because OMOs would be aimed at longer-term price stability.

${ }^{16}$ The transmission mechanism is the process through which monetary policy decisions are transmitted through financial intermediaries to affect the economy in general. As has been amply documented, during the recent global financial crisis this mechanism became impaired in a number of countries.

${ }^{17}$ See Goodfriend and King (1998) for further discussion.
} 
the liquidity to the institution(s) in need. But it is not likely to be true in a stressed market situation - for example, during the global financial crisis (GFC), both in the United States (U.S.) and in the more recent euro area crisis. The Term Auction Facility (TAF) in the U.S. was an effective mechanism, expanding the Federal Reserve's (Fed's) OMO counterparties well beyond the normal small group of (non-bank) Primary Dealers; but not sufficient to meet all market needs because of credit risk concerns in on-lending funds to non-banks. A range of instruments was introduced to meet the varied needs. Collateral limitations within the Eurosystem, on top of a breakdown in the transmission mechanism in conjunction with financial market fragmentation, made the systemic provision of liquidity by the European Central Bank (ECB) through full-allotment longer-term refinancing operations (LTROs) ineffective in satisfying all liquidity needs. Appendix I provides an overview of the major central bank responses to the GFC.

\section{Box 2. Committed Liquidity Facilities: Where Do They Fit?}

Beginning in late 2011, a number of CBs announced Committed Liquidity Facilities (CLFs) aimed at assisting their banks in meeting the Liquidity Coverage Requirements (LCR) envisaged under in Basel III, which are expected to be fully implemented by January $1,2019 .{ }^{18}$ Both the Reserve Bank of Australia (November 2011) and the South African Reserve Bank (May 2012) announced CLFs to help address the shortfall of high quality liquid assets in their domestic markets. Basel III has recognized this as a means through which banks can access a specified amount of liquidity using repurchase agreements. While both the Reserve Bank of Australia and South African Reserve Bank facilities differ in operational features, an element common to both is the commitment by the $\mathrm{CB}$ to provide liquidity to certain eligible institutions against collateral not eligible for OMOs. ${ }^{19}$

These CLFs however differ from idiosyncratic operations discussed in this paper for a number of reasons. Firstly, they are created in response to a systemic shortage of high quality assets within the system - for instance, where the government does not issue a large amount of debt securities. Secondly, CLFs attract a commitment fee designed to reduce reliance on the facility compared to holding high quality liquid assets in normal times. Thirdly, while a bank's request to enter into a CLF is at the CB's discretion, once the fee is paid the $\mathrm{CB}$ commits to satisfy the needs of participating banks against a defined set of collateral, making these akin to an automatic facility. Finally, eligibility criteria apply, particularly in the case of collateral accepted. If counterparty exhausts this collateral set, it cannot access the CLF and will most likely need to mobilize lower quality assets in order to obtain additional liquidity. This is where the LOLR function comes in.

This systemic response function can in some circumstances also be performed by other government agencies. In response to a systemic need and through the use of asset swaps, the government (e.g., via a Debt Management Office) could provide the market with liquid government securities against less liquid assets, for a fee. Norway undertook such an

\footnotetext{
${ }^{18}$ The LCR requires banks to hold a minimum amount of high quality liquid assets to overcome liquidity pressures under certain stress assumptions over a 30 day period.

${ }^{19}$ In the case of the South African Reserve Bank, banks using the facility will be charged a scaled commitment fee (between 10 and 45 bps) based upon each bank's usage of the facility, while the Reserve Bank of Australia applies a commitment fee of 15 bps applied to both drawn and undrawn amounts.
} 
operation in October 2008 when the government introduced a NOK 350 billion market support facility that permitted banks to exchange covered bonds for treasury bills. ${ }^{20}$ Fiscal authorities and other public authorities could also use guarantees (if credible) to restore market confidence and mitigate the risk of contagious deposit runs. During the GFC, the U.S. Federal Deposit Insurance Corporation (FDIC) created the Temporary Liquidity Guarantee Program, which allowed it to guarantee the payment of some senior unsecured debt securities newly issued by commercial banks, and also selected non-interest-bearing transaction accounts, for a fee. A number of countries also increased the amounts covered by their deposit insurance schemes. ${ }^{21}$ Also in the U.S., the Troubled Asset Relief Program (TARP) introduced in October 2008, gave the Treasury the authority to either purchase or guarantee $\$ 700$ billion (later reduced to $\$ 475$ billion) of troubled assets owned by financial institutions. $^{22}$

Table 1. Central Bank Response to Liquidity Problems

\begin{tabular}{|l|l|l|}
\hline $\begin{array}{l}\text { Initiated By and } \\
\text { Type of Operation }\end{array}$ & \multicolumn{1}{|c|}{$\begin{array}{c}\text { Discretionary } \\
\text { Systemic }\end{array}$} & $\begin{array}{c}\text { Discretionary } \\
\text { Idiosyncratic }\end{array}$ \\
\hline $\begin{array}{l}\text { Central Bank, } \\
\text { Systemic. }\end{array}$ & $\begin{array}{l}\text { No additional regulatory oversight; } \\
\text { market rate or possibly a rate } \\
\text { determined by the CB. }\end{array}$ & - \\
\hline $\begin{array}{l}\text { Commercial bank, } \\
\text { Bilateral. }\end{array}$ & - & $\begin{array}{l}\text { Heightened regulatory oversight to } \\
\text { minimize moral hazard; penal rate. }\end{array}$ \\
\hline
\end{tabular}

Source: IMF staff.

The remainder of this paper focuses on some of the operational aspects relating to a CB's provision of bilateral LOLR. It focuses in particular on whether departures may be warranted in crisis situations from the convention of only providing LOLR to solvent banks against "sound" collateral and at penalty rates, and what safeguards should be put in place. Two important issues to consider when formulating policy on such departures are: (i) protecting the CB's balance sheet; and (ii) minimizing moral hazard.

Generally the line taken in this paper is that CBs should have the ability and discretion (but not the obligation) to widen the operational parameters of LOLR beyond banks and against a wider than normal collateral list, subject to strict conditions and only where necessary, to preserve financial stability. This view is informed by the high economic costs typically

\footnotetext{
${ }^{20}$ See www.regjeringen.no for further details.

${ }^{21}$ See IMF (2013) for further details.

${ }^{22}$ See Webel (2013) for a description of the different programs launched under TARP, and Calomiris and Khan (2015) for an assessment of TARP.
} 
incurred in full blown financial crises. ${ }^{23}$ While constraining the degrees of freedom of the $\mathrm{CB}^{24}$ - e.g. prohibiting all support to non-banks - may be appropriate under certain circumstances, this approach ("committing to inaction") runs the risk of being time inconsistent i.e., that it will have to be changed in the face of new unexpected threats over time. Furthermore it requires strong and effective contemporaneous policy measures, e.g., to address evolving systemic risks in sectors or institutions outside of the normal LOLR universe. In practice and as discussed later, the appropriate balance between rules versus discretion will be country specific, reflecting the different market and institutional structures, supervisory capacity, and relative risks faced in different countries.

\section{INSTITUTIONAL ELIGIBILITY}

\section{A. Banks are Special}

In many countries, bilateral LOLR is limited to banks. The 'banks are special' argument, based on their importance to the economy, means that deposit taking can only be undertaken by institutions licensed to do so, and that are appropriately regulated and supervised. The argument is espoused for instance by Gerald Corrigan (2000) who defines banks as "any institution that is authorized to take deposits which are payable on demand at par and readily transferable to third parties." Banks are needed if economic agents are to be able to make non-cash payments for transactions, from accounts where funds are immediately available and whose value is not subject to market price fluctuations. This necessarily involves banks undertaking — and managing — credit risk and maturity mismatches. To protect this function, there is typically a so-called financial safety net comprising deposit insurance (for retail deposits); capital, liquidity and other regulatory requirements (i.e., responsibilities in tandem with the safety net provision); and access to CB liquidity facilities. Importantly, banks pay for the safety net. ${ }^{25}$ Deposit insurance is, over time, funded by a levy on depository institutions; holding capital and liquid assets involves balance sheet costs; supervision is normally funded by a levy on supervised institutions; and LOLR operations typically carry a penalty cost.

\footnotetext{
${ }^{23}$ Laeven and Valencia (2012) estimate the average loss in output resulting from 147 banking crises between 1970 and 2011, as 23 percentage points of GDP.

${ }^{24}$ Prior to the amendment of the Federal Reserve Act by the Dodd-Frank Act, Section 13(3) permitted the U.S. Federal Reserve to provide idiosyncratic liquidity support to individuals, partnerships and corporations. Restrictions on the Fed's ability to give idiosyncratic support provide a recent example of constraints imposed in legislation.

${ }^{25}$ While paying for deposit protection is clearly a cost, banks also receive a benefit—depositors are more willing to entrust their funds to them—so that strong regulation and supervision necessarily accompanies deposit protection.
} 
To the extent the safety net is put in place to protect banking functions, it is not obvious that the same safety net should be extended to non-banks. A depositor needs to trust in a bank's honesty and in its ability to make deposited funds available on demand. An investor needs to trust an asset management company's honesty, but knowingly (in principle) takes on credit and liquidity risk. If LOLR is to be made available to non-bank financial institutions (NBFIs) or financial market infrastructures (FMIs), its format and the conditions under which it might be provided should be determined by the rationale for providing it. There is a temptation to extrapolate from the experience of the GFC, when LOLR was provided to a variety of NBFIs in several countries. But before CB LOLR to non-banks/FMIs is added to the 'normal' toolkit, it is important to consider what the justification is for such lending, what the alternative might be, and whether it would introduce or exacerbate moral hazard.

Whether a CB expects to lend to non-banks or not, or would only do so only under limited circumstances, it is useful for contingency purposes to have the legal authority to do so. There are clear cases from the GFC where CBs (and governments) took the view that some form of emergency support for nonbanks was not only justifiable, but necessary in the circumstances: having the legal powers to respond quickly to such situations is valuable. The absence of legal authority to act in a crisis could exacerbate the impact of the problems, by delaying the CB's ability to respond. Moral hazard that might arise simply from the existence of such a legal authority could be mitigated by a clear policy statement that, for instance, the authorities' presumption is that resolution rather than rescue is the appropriate route of first choice.

\section{B. Nonbank Intermediaries}

It is helpful to consider why NBFIs, or markets, might "need" some type of liquidity support, in order to decide whether CB support is appropriate, and if so, in which form. We can distinguish between principal intermediaries such as central clearing counterparties (CCPs) or securities dealers (SDs), and agent intermediaries, notably mutual funds (MFs) and other asset management companies, that stand between the principals - the borrowers and investors. Systemic risk oversight and crisis management bodies need to consider whether the failure of an intermediary, or group of intermediaries, would have such a damaging impact that some form of official intervention is justified; or if a sudden change in the behavior of users could cause systemic problems.

Principal intermediaries may provide a service to the markets that is important to maintain, most obviously a CCP; whereas in the case of users (of agent intermediaries), it is their response to a loss of funding, or loss of liquid funds, that may have damaging consequences. Principal intermediaries are likely to be supervised entities that provide services important to the effective functioning of financial markets. The users may well be non-financial companies (or individuals), and so not subject to financial regulation and supervision, and lacking any relationship with the regulators. If these borrowers or investors unknowingly (and so, without due controls) take on excessive funding or liquidity risk, their actions in 
response to a shock may cause wider problems, whether by failing to make payments when due (because they have lost funding or liquidity), or by pushing down market prices through asset fire sales, in order to obtain liquidity.

If some form of backstop is deemed appropriate for non-banks then the support - whether liquidity support or some other instrument - should be designed in a way that addresses the specific systemic problems identified; it need not replicate what might be provided for banks. It should not in any case be provided on easier terms than to banks.

\section{Principal intermediaries}

FMIs are increasingly important in managing risk, but by a process that concentrates risk in their operations. Illiquidity in FMIs, particularly in CCPs, could spill over to other market participants and exacerbate financial instability, and in the absence of a resolution framework, might eventually require a bail out at the tax payers' expense. In principle, capital and the use of appropriate margins should protect the CCP against risk of failure by a counterparty. ${ }^{26}$ But it is possible either that (i) market prices move very sharply, such that margin received is not sufficient to cover against the risks; or (ii) in the event of a failure of the party delivering cash, the CCP receives assets (from the other party) of sufficient value, but cannot be certain of obtaining the cash to deliver against them in a sufficiently timely manner.

Many FMIs are considered systemically important in their own jurisdiction. ${ }^{27}$ Well-functioning FMIs can vastly improve the efficiency, transparency, and safety of the financial system. But as FMIs concentrate systemic risk, failing FMIs can be sources of financial shocks, such as liquidity dislocations and credit losses, and a major channel through which these shocks are transmitted across domestic and international financial markets.

For FMIs not eligible for a CB's standing credit facilities or for those that exhaust their eligible collateral holdings, access to LOLR may need to be considered. FMIs' potential access to $\mathrm{CB}$ support has become a particularly relevant issue in the context of moving over-the-counter (OTC) derivatives contracts to CCPs, since this will significantly raise the concentration of liquidity and credit risk. Should loss-sharing mechanisms be insufficient to ensure to continuation of a (systemically-important) CCP's business, the presumption is that LOLR support should at least be considered. The U.S. Dodd-Frank Act permits the Fed to provide credit, in unusual and exigent circumstances, to CCPs; in the euro zone, some CCPs

\footnotetext{
${ }^{26}$ Best practice suggests that CCPs should be able to withstand the default of their two largest counterparties. For a wider discussion on managing the systemic risks relating to CCPs, please see Singh (2014) and Wendt (2015).

${ }^{27}$ The internationally accepted presumption is that in principle all CCPs are systemically important at least in their own jurisdiction. See CPSS-IOSCO (2012).
} 
are legally structured as banks, and so have access to CB standing facility credit in case of need; while in the U.K., the Bank of England (BoE) has explicitly extended the possibility of liquidity support to non-bank CCPs (see Box 3).

Large SDs are another important sub-group in the non-bank category. In some countries, SDs play an important role in supporting secondary market trading and liquidity generally; and their role in repo markets and government securities trading in particular may be an important part of the monetary policy transmission mechanism. ${ }^{28}$ Where possible, a distinction should be drawn between supporting (i) the market-making function; (ii) the SD itself; and (iii) short-term funders of the SD.

The case for supporting the SD function may be strongest for systemically-important SDs trading predominantly in government securities. These are the markets typically most central to money market functioning, monetary policy transmission, and government financing. If government securities become relatively illiquid, the causes for this illiquidity will be important in determining what $\mathrm{CB}$ action, if any, is appropriate. CBs clearly need to understand the market and the business model of SDs in particular, well enough to be able to form a judgment as to when support might be valid. For instance, if illiquidity is a result of perceived default risk, CB market support might equate to monetary financing - if the government defaults, the SDs will not be able to repay any loans - and thus damage monetary policy credibility. If SDs as a group face a loss of funding following a market shock (e.g., a Lehman's-type event), supporting them via repo funding may be important to preserve their market function for the future; though it would also mean bailing out existing funders (and may suggest longer-term a need to review the SDs' funding structure).

An SD may trade not only in government securities but also private sector paper. If the problem arises in non-government paper, but support is still deemed justified, the CB (or government debt management agency) could provide it via an asset swap rather than through an expansion of reserve money. LOLR in the form of an asset swap-e.g., providing liquid government securities against illiquid private sector bonds - may be able to address the underlying needs of the counterparty and so reduce market disruption, without impacting reserve money balances.

In principle, idiosyncratic support for SDs should be rare. If there is no system-wide problem, government securities should be the most liquid (though not necessarily highly liquid) and most creditworthy in a given market; and an idiosyncratic problem need not threaten the market function in general. Moreover, idiosyncratic LOLR should probably only be considered for a subset of SDs in a market: SDs that are OMO counterparties (assuming some SDs meet this requirement); or those SDs deemed to be systemically important,

\footnotetext{
${ }^{28}$ In some countries, a few large SDs are OMO counterparties (typically called "Primary Dealers"); in some markets they may be designated market-makers, supporting secondary market trading.
} 
whether or not they are OMO counterparties. The failure of a small SD - and in some markets there are a large number of SDs - is unlikely to give rise to systemic problems.

Any NBFI in receipt of LOLR from the CB should be subject to enhanced supervision and conditionality. This is required so that the $\mathrm{CB}$ has comfort that the monies lent can be repaid and that the funding is being used for appropriate means. But NBFIs are unlikely to fall under the direct regulation and supervision of the $\mathrm{CB}$ and, in this instance memoranda of understanding (MOUs) with the supervisor(s) will be needed to facilitate cooperation and sharing of confidential information. Such MOUs should ensure that the CB has the ability to request whatever information, and apply any conditionality, it deems necessary (including enhanced supervision) to recover the funds it provided.

Creditors of an SD could be exposed if an SD fails because of ill-judged interest rate risk. An unexpected upwards shift in the yield curve could leave an SD with short-term funding and long-term securities holdings facing an increase in funding costs and losses as bond prices fall. If the CB provides LOLR - at below market rates - to replace funding, then existing creditors might be bailed out without loss, and the SD would benefit from a funding subsidy. If the SD is allowed to fail, then repo lenders (creditors are likely to be repo lenders) could suffer some loss if the value of the securities held is lower than funds lent; but provided there is no credit risk - i.e. higher yields do not suggest a government default - the securities could be used as collateral if the creditors have immediate need of liquidity. Any LOLR support that bailed out creditors would require a judgment that the impact on the creditors of such losses could have systemic consequences.

\section{Agent intermediaries}

During the GFC, the reliance by economic agents on non-bank credit channeled via agent intermediaries e.g. mutual funds and money market mutual funds (MMMFs) was in some cases so large, that a breakdown in this credit intermediation channel could have caused significant economic dislocation. From the point of view of the borrowers (issuers of commercial paper that was purchased by MMMFs, for instance), the investors' withdrawal might equate to a credit crunch, depending on the ease/difficulty of substituting into other borrowing instruments and frictions in the financial system. Understandably, authorities provided support in 2008 both to investor-creditors (e.g., MFs and MMMFs), but also to borrowers (e.g., U.S. issuers of CP, and some European banks which had borrowed USD from U.S. MMMFs), in order to minimize economic disruption. ${ }^{29}$

In the case of non-bank borrowers funded via NBFIs, the CB could in principle act as LOLR. But the $\mathrm{CB}$ is unlikely to be able to do so directly with a large number of counterparties, as it

\footnotetext{
${ }^{29}$ The authorities should consider, ideally preemptively, whether the activity itself displays inherent weaknesses (involving for instance 'privatization of profits, and socialization of losses') that need to be addressed.
} 
would lack the information about and relationship with the borrowers. It may be possible to do so indirectly: a few governments and CBs did so during the GFC. For example, the U.S. TARP provided some support to auto manufacturers as well as to financial companies; and the U.K. Treasury and BOE launched a "Funding for Lending" scheme in 2012 to incentivize bank lending to the real economy.

In the case of investors, the "demand" for NBFI LOLR may arise because of an underestimation of (or under provision for) liquidity and credit risk. In some cases, financial intermediaries offer products which look very similar to banking deposits-e.g., a MMMF investment which has a stable (notional) value, and is readily convertible into cash and transferable at least under normal market conditions - but which are fundamentally different. The investment is clearly less liquid than a bank deposit; but if the investor is persuaded that the difference is minimal - and this may be particularly true in the case of (open-ended) MF investments - then the higher return appears clearly to outweigh the marginal loss of liquidity. ${ }^{30}$ MMMFs in some countries are a case in point. They are used by individuals and corporates (including institutional investors such as pension funds) as "cash equivalent", and are consequently susceptible to runs if there are concerns about the value or tradability of the assets in which they invest.

It may be possible to extend the concept of "circuit breakers" used by some regulators to suspend trading in assets when price-movements exceed a pre-defined threshold (which could be varied in response to market circumstances). Circuit breakers are normally used to give the market a "breathing space." They might prove difficult to apply to non-exchange traded products, such as MFs. However, it would be useful to consider whether some constraints could be placed on the fire-sale of securities by asset managers. ${ }^{31}$ In the case of MFs, for instance, the obligation to "redeem" investments within seven days-which could force a fire sale — could be suspended by the securities regulator. ${ }^{32}$ These constraints would not prevent disruption caused by investors unexpectedly losing access to liquidity; but they would limit the spillover to other sectors of the economy.

\footnotetext{
${ }^{30}$ Since asset managers act, legally, as agents, they do not need to bear the regulatory costs of capital, liquidity buffers, contributions to deposit protection funds etc; but investors may nevertheless expect the state to provide a backstop. This expectation could be changed, in part by addressing marketing of such products. Regulators should insist that clear "health warnings" are displayed, and that non-professional investors are proactively advised of the liquidity risks.

${ }^{31}$ Circuit breakers can in principle impact "redemptions" in funds now: a prospectus will typically say that redemptions may be suspended or payment dates postponed when the stock exchange is closed (other than weekends or holidays), or when trading is restricted, or as permitted by the regulator.

32 This may operationally be difficult. If the suspension of "redemption rights" were to be preemptive, it would need to be extended to MFs that were not experiencing a run. Given the wide variety of assets in which MFs may invest, regulators would be unlikely to want to suspend redemptions in all funds; while defining a group of sufficiently homogenous funds would be difficult.
} 
The most effective approach with respect to non-banks offering "cash equivalent" products may be pre-emptive regulatory measures. Thus, LOLR should be seen as a possible but nonessential part of the authorities' response. Regulatory measures would involve reducing the risks arising from a mismatch between the expectations of the investors and borrowers - at the extreme, one assuming that an investment carries no real credit or liquidity risk, and the other assuming that a term funding need can be reliably met by rolling over short-term financing. Specific measures to achieve this might include:

- Institutional investors could be prohibited from treating investments as equivalent to cash, since the funds do not benefit from the liquidity protections required of banking deposits. $^{33}$

- $\quad$ Asset management funds could be required to make clearer, including in short-form prospectus documentation, that there is no liquidity guarantee (the investor's "right of redemption" is not matched by an obligation on anyone to purchase the assets which must be sold if the investor's right is to be upheld).

- Minimum investment or transaction amounts could be introduced to reduce the risk of retail customers investing operational balances in risky products not covered by the financial safety net.

- Gates and fees can be put in place in the case of a "run"; asset managers should have clear plans as to how and when these would be used - not least since the risk of gates being imposed may in itself provoke a run.

Conditionality may be difficult in the case of borrowers and investors. If the authorities step in to provide funding (or guarantees) to nonbank companies that had borrowed from agent intermediary NBFIs, it should be possible in theory to impose conditionality; but this would likely be of a different nature to that which might be imposed on NBFI beneficiaries of LOLR (financial sector regulation and supervision would not reach across to nonfinancial companies). The behavior of "exiting" investors in particular could cause systemic problems, and may need to be addressed. However, if liquidity were provided to a fund - the agent intermediary - to allow some investors to exit without market disruption, conditionality would have to be imposed on remaining investors, but in order to benefit those exitingunless a mechanism could be found for lending to a large number of unregulated exiting investors. $^{34}$

\footnotetext{
${ }^{33}$ This does not mean institutional investors could not use them, but that the treatment should be differentiated from cash.

${ }^{34}$ This may explain why in 2008 the U.S. Treasury provided a guarantee to MMMF investors- to stop them exiting - rather than lending to the MMMFs.
} 


\section{Box 3. Growing Importance of Lender of Last Resort for Central Clearing Counterparties}

The 2009 G20 requirement that all standardized OTC derivatives should be centrally cleared has put the importance of liquidity backstops for CCPs firmly in the spotlight. The GFC exposed weaknesses in the structure and operations of the OTC derivatives markets that contributed to global systemic risk. Although the crisis did not originate in these markets, their size, interconnectedness and lack of transparency aggravated financial stress. Subsequent regulations e.g., the Dodd-Frank Act in the U.S. and the European Markets Infrastructure Regulation (EMIR) require central clearing of standardized OTC derivatives contracts, thereby increasing the volumes cleared through CCPs.

Policy makers have recognized that liquidity management of CCPs is important from a financial stability perspective. The Financial Stability Board's (FSB's) third progress report on the implementation of the OTC derivative markets reforms outlines "four safeguards for a resilient and efficient global framework for central clearing", one of which is "appropriate liquidity arrangements for CCPs in the currencies they clear" (p.3) ${ }^{35}$ The Economic Consultative Committee (an informal group within the Bank for International Settlements (BIS) that includes, amongst others, all Governors participating in the BIS Board Meeting) states that $\mathrm{CBs}$ are working towards a regime that ensures there are no technical obstacles for the timely provision of bilateral LOLR by CBs to solvent and viable CCPs, without pre-committing to the provision of this liquidity. ${ }^{36}$

Several CBs have arrangements in place to provide CCPs access to standard operations. For example, Eurex Clearing, the Germany based CCP, and LCH. Clearnet SA, the France based CCP, have a banking license, which provides them access to "normal" CB liquidity. The BOE implemented in November 2014 an extension to its Sterling Monetary Framework to broker dealers and to central counterparties. Other CBs that can provide LOLR to CCPs include the Sveriges Riksbank and the Swiss National Bank.

\section{Solvency And ViabiLity ${ }^{37}$}

\section{A. Not Just a "Point-in-Time"Assessment}

As noted earlier, LOLR is a concept traditionally associated with solvent but illiquid banks. The aim is to support a viable bank (and thus confidence in banks in general), providing a breathing-space to restore normal functioning. This approach may read across to CCPs, but less easily to SDs, and not to agent-intermediaries.

However, differentiating liquidity from solvency problems in a bank is not easy in practice. ${ }^{38}$ While illiquidity is relatively straightforward to identify - by banks being unable to meet payments due - in crisis times illiquidity and solvency issues tend to become inextricably

\footnotetext{
${ }^{35}$ See FSB (2012).

${ }^{36}$ Ibid p.48. The safeguard states that CCPs must hold adequate liquid assets or have adequate lines of credit in all of the currencies of the products cleared by the CCP.

${ }^{37}$ See Appendix II for a discussion on stakeholder coordination.

${ }^{38}$ It is generally the case that minimum regulatory levels of capital form the basis for the assessment of solvency. An institution may have positive net assets — and so technically is not insolvent — but still be undercapitalized.
} 
linked, making the assessment of solvency more difficult particularly when timelines are tight. There are three main reasons why the assessment of solvency can be difficult:

- First, in crisis times the mark-to-market value of financial assets can be become extremely volatile, making the true assessment of solvency difficult. (Forced asset sales in such circumstances mean that illiquidity may quickly turn to insolvency.) An example would be the liquidity crunch faced by Lehman Brothers, when the Fed's asset valuation took place at a time of economic uncertainty and investor unease. Similarly, when Eurosystem LOLR was extended to Greek banks in 2011, ${ }^{39}$ assumptions regarding the solvency of the Greek sovereign were crucial as the banks receiving LOLR were large holders of Greek government bonds. ${ }^{40}$

- $\quad$ Second, the valuation of non-tradable assets (e.g., loans) and collateral (e.g., commercial property, or industrial inputs funded by short-term commercial bills) may lie beyond the CB's scope of expertise, and can be significantly impacted by macroeconomic or sociopolitical shocks.

- $\quad$ Third, BIS (2014) suggest that there is scope for the solvency assessments by supervisors or analysts to be biased. Supervisors may wish to avoid the reputational risk of identifying a case of insolvency 'under their watch' and the potential systemic consequences that could come with this. ${ }^{41}$

Some CBs are now reexamining the approach to LOLR solvency requirements. In its 2015 consultation paper, the Bank of Canada is considering replacing its solvency requirement with a requirement for the concerned entity to have in place a credible recovery plan (i.e., a demonstration of viability) and resolution framework. In some cases, a requirement to assess solvency is embedded in LOLR legislation; and the standard solvency assessment can form part of the CB's overall consideration, even if it does not adhere to it. From an operational perspective, while compliance with regulatory ratios could be a starting point, judgment could also include qualitative elements, such as the market's perception of the institution.

The assessment of solvency can also be "dynamic" and here it is useful to distinguish between "a point in time" assessment, where the solvency of the institution is assessed at the time of the application for liquidity support-likely based on the most recent available supervisory data reports — and a "forward looking" assessment, where the expected solvency

\footnotetext{
${ }^{39}$ See for example, Reuters article of September 3, 2011 available at www.reuters.com.

${ }^{40}$ Recapitalization via government bonds may not convince market counterparties, e.g., if it is difficult to demonstrate the real value of unfunded non-marketable securities.

${ }^{41}$ Moreover, in many financial systems, banks share exposures to certain debtors and sectors, and if the solvency of one institution is in doubt in crisis times, it will be expected that the solvency of other institutions will also be uncertain, even if difficulties have not yet fully materialized.
} 
is assessed over the near-term. No matter the level of capital at the outset, there may be a risk that the institution will suffer continued losses and so become insolvent during the life of a potential liquidity support operation. Such concerns may arise from an assessment of the exposure of the entity to what may be or become an underperforming part of the economy in the near future. ${ }^{42}$ This could involve, for example, exposure to hotels and restaurants in a region now shunned by tourists, or to a business that has been bypassed by technological innovation.

The assessment could also incorporate an examination of the entity's "viability", to provide confidence that the recipient will be able to repay the LOLR funds. A viability assessment is "business model"-focused, undertaken to determine that the entity can reasonably be expected to have continued potential for generating sufficient cash flow to repay the LOLR. A bank that has sufficient capital today but is expected to run losses for the foreseeable future would not be viable. ${ }^{43}$ Indications of non-viability could include:

- $\quad$ A business model that relied on the ready availability of cheap short-term funding and a positively-sloped yield curve, both of which have disappeared in an (post-GFC) environment of increased market risk aversion and a flattening of the yield curve.

- $\quad$ An entity that has a poor corporate governance structure and/or a poor risk management culture. ${ }^{44}$

Funding asset management companies that could take years, if not decades, to run down an asset portfolio, are a fiscal rather than a central banking task. These situations call for developing plans for transferring a bank's deposits and performing assets to another entity (a bridge bank). ${ }^{45}$ In some jurisdictions such entities may not need to satisfy regulatory requirements immediately after their creation, but would be expected to do so within a clearly defined timeframe. State support—whether implicit or, preferably, explicit — may provide the $\mathrm{CB}$ with a level of comfort, so that bilateral LOLR could be extended in the short-term, in the absence of other viable funding alternatives. In such a scenario, and in

\footnotetext{
${ }^{42}$ Such a forward-looking approach is something the ECB caters for by forming an “... assessment, over the short and medium term, of the liquidity position and solvency of the institution receiving the ELA, including the criteria used to come to a positive conclusion with respect to solvency". See ECB (2013).

${ }^{43}$ In the case of the Riksbank, "Solvency assessment is aimed at assessing long term survival capacity of an institution, including its balance-sheet solvency, business model, profit generation capacity, and capacity to resolve capital problems without further public interventions, even if the bank momentarily does not meet the capital adequacy requirements." See IMF (2011).

${ }^{44}$ See for example, Financial Stability Board (2014).

${ }^{45}$ Hoggarth et al. (2004) describe a bridge bank as an entity controlled by the liquidator, taken into temporary state-ownership in order to permit its restructuring and ultimate private sale.
} 
addition to the general eligibility criteria for such operations, binding agreements on the extent of the restructuring, the establishment of strict timelines with regard to the conclusion of restructuring and the ability to impose conditionality should be agreed ex ante. ${ }^{46}$

\section{Box 4. Lender of Last Resort and Resolution}

From a theoretical perspective it may make sense to immediately resolve a failed bank; but practically it may not be straightforward. In most countries, the legal framework for orderly resolution, and the planning and other reforms necessary to make it effective, are not yet fully in place and the failure of an (insolvent) bank may trigger financial instability. CB funding of insolvent banks is a break from past convention and may exacerbate moral hazard effects.

However, in certain limited cases bilateral LOLR may be needed as a temporary backstop. For example, LOLR may be required, while plans to create a bridge bank or recapitalize the failed entity are put into effect. In such circumstances, in addition to the usual requirements attached to LOLR, the CB should consider the following:

- Corporate operations should be restricted to core activities, while efforts are undertaken to ascertain the likely prospect for recapitalization or restructuring. ${ }^{47}$

- In the absence of realistic time-bound recapitalization or resolution plans the entity should not be supported. $^{48}$

- Insolvent banks and banks with capital levels below the minimum regulatory requirements should not be eligible for monetary policy operations. However, their prohibition from monetary policy operations needs to be carefully managed, to allow continued access to payment and settlement systems, and communicated, to avoid the risk of provoking a deposit run.

- $\quad$ Bilateral LOLR to entities which may not be solvent should be fully indemnified by the government, in order to protect the $\mathrm{CB}$ balance sheet. This requirement is particularly important as, in the absence of an indemnity; the $\mathrm{CB}$ may be forced to monetize any losses associated with the provision of liquidity support - endangering the effective implementation of monetary policy.

In limited circumstances when financial stability needs to be preserved and with adequate safeguards, a CB may need to provide liquidity support to entities that while insolvent are seen to be viable (see Box 4). For example, the CB might have received comfort from the fiscal authorities that the institution will be recapitalized at a predetermined date in the near future, and that it has a viable business model longer-term. ${ }^{49}$ Under such circumstances it may be reasonable that LOLR could be extended to systemic entities whose solvency

\footnotetext{
${ }^{46}$ It may not be possible to clearly establish at the outset an exact maturity date for the operations, however, adequate incentives should be put in place so that the restructuring concludes within an agreed timeline.

${ }^{47}$ Careful consideration needs to be given the form of liquidity support provided as such actions could create significant stigma for sound banks. As Paul Tucker outlines "if it is believed that the central bank will not turn away insolvent banks, then it becomes toxic for a solvent but illiquid bank if there is any chance of that becoming known.” (p. 20). See Bank for International Settlements (BIS) (2014).

${ }^{48}$ The liquidity support should be time bound and in no way be seen as a substitute for the development of crisis management plans and appropriate resolution measures.

${ }^{49}$ Some may consider that if a government undertakes an obligation to recapitalize an institution, there is little preventing the institution being recapitalized immediately. However, the inability to access debt markets quickly or due process requirements may preclude the government from affecting this immediately.
} 
concerns will be resolved with certainty and within a short time frame; ${ }^{50}$ and in the interim, the $\mathrm{CB}$ could require an indemnity from the government to protect its balance sheet (see Box 5).

\section{B. "Systemic-ness"}

It is sometimes argued that LOLR should be provided for financial stability purposes or only to systemically important institutions, whether banks (SIBs) or other financial institutions (SIFIs). Such an approach aims to avoid putting public funds unnecessarily at risk; but it can create moral hazard — the 'Too Big to Fail' problem—as only SIBs and SIFIs benefit from potential support.

For many CBs, systemic importance is only a consideration for non-banks, for example, as proposed by Plenderleith (2012) in the case of the BOE. While the failure of a small bank during "normal" times may not be systemic, during a period of heightened tension in the financial markets its failure may well be. Moreover, it does not obviously make sense to let a bank judged to be solvent and viable fail; e.g., because of unfounded speculation, simply because it is not as big as other banks, while there is always some risk of contagion when allowing any bank to fail. Supporting the bank may be cheaper to the authorities than resolution, making the case for supporting all regulated banks - that are clearly not insolvent and are viable_-very strong.

Most CBs can lend to all regulated banks, systemic or not. In the case of the Eurosystem, the potential systemic consequence of the situation at hand is taken into account when the provision of idiosyncratic LOLR is being considered by national CBs (ECB, 2013). A number of euro zone jurisdictions, such as Ireland and Finland, make specific reference to preserving financial stability. But in a few cases - the Swiss National Bank for example - the $\mathrm{CB}$ distinguishes eligible banks in terms of their systemic importance, amongst other criteria. ${ }^{51}$ This should reduce the frequency with which public funds are put at risk, and signal that non-systemic banks will be allowed to fail. However, confining LOLR to systemically important banks may raise equal-treatment issues due to the extension of an implicit subsidy to these entities. Furthermore, if the systemic determination is made at a fixed point in time, then time consistency could be a problem as disorderly failures of even relatively small banks can be systemic at times of heightened depositor concern.

In principle, CBs should develop frameworks for assessing systemic importance that reflect both the intrinsic features of an individual institution and the financial and economic circumstances. A number of factors could be taken into account, including:

\footnotetext{
${ }^{50}$ This of course assumes that the recapitalization is a binding and irrevocable commitment of the government and a change of government would not void this obligation.

${ }^{51}$ See www.snb.ch/en/iabout/finstab.
} 
- Size, as measured by its market share of deposits and lending; its activity in the interbank market; its importance in the payment system (volume and geographical reach).

- Complexity, as this may increase the risk of a disorderly resolution, and of unforeseen problems emerging.

- Services provided, if they are unique or only provided by a small number of other institutions, as it may be difficult to replace the functions concerned.

- Interconnectedness with the financial system, in terms of bilateral exposures (e.g., in the derivatives market), or of the capacity to magnify the initial shock and cause turbulence in asset markets (leverage).

- Risk of contagion e.g., from a wholesale or retail deposit run, or from the fire sale of assets. $^{52}$

It would be important that CBs adopt arrangements, including necessary information and data collection, to allow the quick assessment of systemic importance of any financial institution at any given point in time. These should enable the $\mathrm{CB}$ to run a systemic impact assessment at short notice and decide in a timely fashion whether an institution could receive LOLR or not, if a systemic test is applied. While it is possible to objectively quantify market share for a given set of products, some of the relevant indicators are more subjective. For example, there may not be an immediate and clear-cut answer on the likely impact on the provision of credit, asset prices, and the real economy. ${ }^{53}$

\section{TACKLING Fire SALES}

Fire-sale of assets may reflect the sale of fixed-income assets by holders who need cash and had over-relied on the liquidity of the asset; or a response to stop-loss orders by investors who are worried that the market adjustment still has some way to go. In some cases-e.g., mutual funds, exchange traded funds - investors may have assumed that tradability equates to reliable market liquidity; and in order to obtain needed cash they may have to sell the asset regardless of a (perceived short-term) price fall. ${ }^{54}$ The same may hold true of short-term cash

\footnotetext{
${ }^{52}$ See, for example, BCBS (2013a) for a discussion on the assessment methodology for globally systemic important banks.

${ }^{53}$ In such instances an element of judgment is unavoidable. For example, while it is not always true, it is highly probable that the removal of a bank branch network from a market will have a significant impact-be it for a limited time —on the local economy.

${ }^{54}$ This misperception is not entirely surprising, as (open ended) mutual funds typically have an obligation to "redeem" shares with seven days' notice (and in practice do so sooner). Since no entity has any obligation to buy the shares which are 'redeemed', the mutual fund will reserve the right to deliver assets (securities) rather
}

(continued...) 
lenders in the repo market, where the cash borrower defaults: they may have no expectation of being left holding the asset, and no experience of managing such assets (or in some cases no legal authority to do so). ${ }^{55}$ In other cases, the desire to sell may be generated by expectations of future price falls, rather than an immediate need for cash. In either case, these fire sales can spill over into other market segments as portfolios and collateral are marked to market, and lead to losses as intermediaries sell assets to meet margin calls, liquidity pressures, etc. It is useful to distinguish two drivers of fire sales:

- The reason for the investor selling is to obtain cash. If the need to sell is driven by a need for cash, perhaps to meet margin calls, near-term payments, etc.- - then lending against the asset may meet the investor's requirement (the investor in this case may be a bank, but could be an NBFI, or nonfinancial institution; or even a large number of individuals who, acting in a similar manner, could have market impact). Depending on the situation, lending liquid securities (an asset swap) may be more effective than lending reserve money.

- The investor's primary goal is to limit exposure to further price falls. In this case, lending against the asset may not help, since the goal can only be met by selling the asset outright. But finding a price at which investors are willing to sell and the $\mathrm{CB}$ can reasonably buy may prove difficult. It is not clear that the CB should pay a price substantially above the market rate for an asset; and in any case, buying the asset even at the "market" price could still involve considerable credit risk for the CB. Some suggest that the CB could act as "market maker of last resort"; but in stressed circumstances, where there are no market buyers, this would likely mean "purchaser/underwriter of last resort."

\section{A. Recourse versus Non-recourse Lending}

Asset fire-sales may be difficult to tackle without the authorities taking on some price risk. CB lending is normally collateralized, and with recourse to assets placed as collateral. Collateral is taken both to reduce risk to the $\mathrm{CB}$, and to limit the amount that can be borrowed ${ }^{56}$ But primary recourse is to the borrower, and the borrower's liability is not affected by the performance of the collateral. Such lending can be very effective in providing cash, but does not change the borrower's credit exposure to the collateral. To remove

than cash, or to suspend redemptions. In practice, delivering assets does not happen, and suspending redemptions would likely lead to closure of the fund.

${ }^{55}$ Arguably, if an institution cannot legally own an asset, it should not lend on repo against that asset.

${ }^{56}$ If a borrower did not need to provide collateral, the $\mathrm{CB}$ would need an alternative mechanism to limit its borrowing. There is no obvious reason why a firm should need to borrow more than 100 percent of its assets i.e., LOLR should not be provided to support new lending by a bank, or to support more leveraged activity. 
exposure, the investor needs to sell the asset, or obtain a guarantee, or perhaps buy a putoption of some sort.

Non-recourse lending with a suitable haircut might be a useful tool to address the credit-risk aspect of asset fire sales. ${ }^{57}$ If an asset price has fallen $\mathrm{X}$ percent, and investors are forced to sell either because they need cash, or in order to draw a line under potential losses, the CB could lend on a non-recourse basis, at a penalty interest rate, and with a haircut to the distressed market price of (say) a further Y percent. The investor now has cash equivalent to (100-X-Y) percent of the pre-crisis price, and is exposed to a maximum Y percent further price fall. ${ }^{58}$ The $\mathrm{CB}$ would clearly be exposed to credit risk if there is a large and persistent further fall in the asset's value, so it is recommended that the CB be fully indemnified by the government for these operations. But there is no way to remove credit risk from the market without the authorities (i.e., ultimately the government) taking on that risk.

Determining the appropriate haircut for non-recourse lending-especially where a wide range of securities and issuers may be involved - is difficult, but critical to its success. Too large a haircut might inflict (perceived) excessive losses on investors and so fail to prevent the risk of a fire-sale; too low a haircut puts excessive risk on the authorities and increases moral hazard. But while difficult, the pricing may be easier than if the $\mathrm{CB}$ were to act as 'investor of last resort' by simply purchasing the assets outright.

If asset fire sales are prompted by a combination of a need for cash, and a desire to remove or limit credit exposure, the CB could offer a combination of recourse and non-recourse lending (assuming the situation warrants a systemic response). Recourse lending is better from the CB's point of view, and involves less moral hazard, so could be offered on easier terms. For instance, in the event of a situation demanding a systemic response, the CB could offer a choice, for a given asset class, of lending (i) with recourse, at the policy rate plus 100 basis points (bps) and an X percent haircut on the asset; or (ii) non-recourse lending, at the policy rate plus $150 \mathrm{bp}$, a fee of $25 \mathrm{bp}$ and a haircut of $2 \mathrm{X}$ percent.

Non-recourse lending is similar to selling a put option to the market. If the price of the asset does not fall as far as feared, then the borrower has an incentive to repay the loan and take back the collateral: this option may indeed make non-recourse borrowing more attractive to the market than an outright sale of the asset. If the market need is to limit credit exposure, then the CB (or the government) could sell a put option instead of non-recourse lending: this would address price risk and so forestall fire sales, but without injecting reserve money into the system.

\footnotetext{
${ }^{57}$ The U.S. Federal Reserve Bank used a number of instruments with non-recourse lending during the GFC.

${ }^{58}$ With a non-recourse loan, if the price falls below the amount of cash provided, the investor-borrower can walk away from the loan contract, with no recourse by the lender.
} 
Some of the operational issues involved in CB lending to entities that it does not supervise could be addressed by operating such a scheme via those banks which are already CB counterparties. It would be operationally difficult to deal with a very large number of new counterparties and assets, while too limited a universe may render the tool ineffective. If a bank customer (probably a limited type of entity only, e.g. a regulated NBFI) can borrow on a non-recourse basis from its bank against certain assets, and the bank can-in a back-toback transaction-borrow from the $\mathrm{CB}$ on the same terms, there would be no need for the $\mathrm{CB}$ to create and manage new counterparty relationships.

\section{Key Operational Challenges}

\section{A. Short-term or Long-term?}

The duration of support should reflect the root cause of the issue and should not be provided for longer than necessary. He (2000) suggests that reliance on CB assistance for a period longer than a few weeks indicates that an institution may have more acute difficulties, such as insolvency, that may be masked by the continued provision of idiosyncratic support. The prolonged provision of liquidity, likely reflecting the fact that the rest of the banking sector is reluctant to engage with the entity, could make it difficult to distinguish a solvency from a liquidity need. Some CBs address idiosyncratic needs for liquidity for as short as a week, which are then reviewed and rolled from week to week, allowing longer provision. Other CBs operate under or announce limits of anywhere between one month and three months. ${ }^{59}$

However, it is not always easy to determine what is meant by "temporary." The GFC has shown clearly that liquidity problems even in otherwise viable banks may persist for several months and even years where financial market fragmentation has become entrenched and asset quality problems remain unresolved. This may require the CB to take a more flexible approach. In the euro zone, some banks are still benefiting from LOLR support some six years after the start of the crisis. In both the U.S. and the U.K., the CBs provided financing to banks for longer than normal; subsequently Quantitative Easing policies injected substantial volumes of reserve money into the banking system that reduced the need for banks to seek LOLR support.

Whether the initial LOLR maturity is relatively short or not, time-limited provision of support is desirable as it dissuades the market from seeing the lending arrangement as an open ended facility, provides a clear point at which to review the situation, and encourages

\footnotetext{
${ }^{59}$ For example, see Article 16 (1) of the "Law on the Bank of Albania" No. 8269, dated 23.12.1997, www.bankofalbania.org; Section 36 (1) of the Basic Constitutional Act of the Central Bank of Chile www.bcentral.cl; and, Article (59) of the Central Reserve Bank of Peru Organic Law www.bcrp.gob.pe, The HKMA is permitted to respond to idiosyncratic liquidity needs for an initial term of 30 days, which can be rolled for a further 30 days on maturity.
} 
supervisors and resolution authorities to resolve the troubled entity if recovery is not foreseeable in a reasonable time-frame. ${ }^{60}$ The inclusion of binding maturity limits in LOLR legislation would have to be carefully considered; should the maturity be too long, (political) pressure may be put on the $\mathrm{CB}$ to lend for longer than warranted by the liquidity need, while should the limit be too short, the flexibility of the CB's response may be constrained.

No matter the term, it is prudent to develop funding plans early in the process, in conjunction with the supervisor, in order to establish the likely scale of the liquidity need and the identification of a clear end-date to its requirement. At all times during the provision of LOLR the institution, in conjunction with the supervisor, should demonstrate a reasonable prospect of its ability to repay the liquidity provided on or before the maturity of the arrangement. Funding plans should have clear and verifiable targets, and failure to meet these should trigger escalating supervisory actions. While it may be difficult to develop these within a short time-frame, initial LOLR loans could be for short maturities, pending approval of a plan, while failure to provide a plan should itself carry resolution consequences. Such constraints can be incorporated into the funding plans (and be modified if there is a strong case).

\section{B. Cost}

The approach to pricing of LOLR adopted by CBs varies considerably. Some, such as the $\mathrm{ECB}$, are said to apply a fixed spread over the CB's overnight lending facility, irrespective of market conditions. ${ }^{61}$ The Hong Kong Monetary Authority (HKMA) establishes its rate on the basis of its policy rate plus a spread taking into account current market conditions; while the Bank of Canada appears to have charged its bank rate when conducting these operations. ${ }^{62}$ The BOE suggests that the rate should not be fixed i.e. it should be dependent on the circumstances and the counterparty, ${ }^{63}$ and that there should be a high fee to discourage use and so minimize moral hazard; but that costs should not be so high as to accentuate the strains the LOLR is seeking to alleviate. A similar approach is to charge a high rate at the outset of the operation, and reduce it over time. This "reduction approach" uses high rates for relatively short-term LOLR (e.g., up to one month), to deter banks from accessing LOLR

\footnotetext{
${ }^{60}$ Some central banks in emerging markets have provided LOLR support for three-five years, without regular reviews or strong supervisory intervention or control, reducing the incentives for weak institutions to tackle underlying problems.

${ }^{61}$ Some estimate this spread to be between $100 \mathrm{bps}$ and $150 \mathrm{bps}$ over the ECB's marginal lending facility. See https://mninews.marketnews.com, October 18, 2013.

${ }^{62}$ See HKMA policy statement on LOLR (last version August 1, 2011) available at www.hkma.gov.hk. In the case of the Bank of Canada, please see their LOLR policies available at www.bankofcanada.ca.

${ }^{63}$ The rate could be higher for those entities with poorer risk management and more illiquid collateral. See Plenderleith (2012).
} 
when there are genuine alternatives; and imposes a lower penalty rate for longer-term needs since (i) increased supervisory scrutiny of the institution imposes different costs and provides the $\mathrm{CB}$ with some comfort and (ii) too high a rate could exacerbate the institution's problems.

It is sometimes suggested that CBs should apply "market rates". However, there is unlikely to be a genuine market rate for an illiquid institution: if funds were available in the market, the institution should not need LOLR support. CBs need to strike a balance between providing incentives for a distressed institution to seek alternative funding, and moral hazard if LOLR is too cheap.

In the case of systemic lending - "emergency" or "exceptional" liquidity assistance, where a substantial part of the banking system is obtaining funding from the CB-the lending rate cannot be penal, since this rate will determine short-term interest rates. In such

circumstances, the CB could raise its policy rate to a level higher than previously. This would constitute a monetary policy tightening, and may in some circumstances be appropriate e.g. if there is an associated balance of payments crisis; but it may not be appropriate e.g. in the U.S. and the euro zone during the GFC.

\section{Adequate Collateral}

The standard of collateral accepted in an idiosyncratic response is typically different to that with a systemic response. In the case of a systemic need for liquidity, it is generally a blockage within the system that prevents the collateral being used in the market, rather than an issue with the collateral itself. On the other hand, in the case of an idiosyncratic liquidity need, the concerned institution is likely to have exhausted its high quality assets, and the CB may have to accept many types of unencumbered assets, provided (i) ownership can be legally transferred; (ii) it can be priced; and (iii) the asset, including associated risks, can be managed by the CB. ${ }^{64}$ By necessity, Bagehot's principles of only lending against 'good' collateral may not always be feasible to apply in the case of bilateral LOLR, but the collateral accepted should always be adequate to cover anticipated losses at that point in time. Appendix III provides guidance on key issues CBs may face when considering what collateral to accept in bilateral LOLR.

At a minimum the CB should ensure that it has good legal title to the collateral accepted, as without this, any liquidity provided would essentially be equivalent to an unsecured loan. ${ }^{65}$

\footnotetext{
${ }^{64}$ Some CBs have limits on the amount of monetary policy lending that can be accessed by an individual institution, or have concentration limits in terms of collateral presented. When these limits are breached, and while the bank may continue to hold monetary policy eligible collateral, it may be asked to apply for idiosyncratic liquidity support.

${ }^{65}$ For instance, the authors are aware of one case where a central bank, after a prolonged court case lasting several years, lost title to a commercial property asset taken as collateral.
} 
Thorough due diligence should be undertaken before collateral is accepted, along with ex post verification checks. In addition, while it makes sense for a $\mathrm{CB}$, to the extent possible, to minimize credit risk and liquidity risk, handling and administrative costs are an important additional consideration. Thus, while a portfolio of loans to small and medium-sized enterprises may have low credit risk, they would be illiquid and cumbersome to manage in case of need, particularly as a large number of loans might need to be mobilized. In some jurisdictions, taking and using loan book collateral is legally difficult or even impossible (for instance, the Civil Code in Russia at one stage limited the use of such collateral). ${ }^{66}$ As part of recovery and resolution planning, authorities should consider steps that could be taken by banks taken to pre-position collateral given such constraints e.g., to amend loan documentation to facilitate title transfer. ${ }^{67}$

\section{Box 5. Indemnities}

The provision of idiosyncratic LOLR involves lending to illiquid institutions generally against lower quality collateral, which puts public funds provided at risk. The CB could consider seeking a government indemnity when the CB has concerns about the quality of the counterparty (e.g., solvency is not clear), the collateral presented by the institution, the size or length of support, or the exit strategy. This obligation would undertake to make good any CB losses associated with the provision of LOLR and should be unconditional and irrevocable, and callable on demand by the $\mathrm{CB} .{ }^{68}$ In this regard, the CB should devise and agree on a procedure with the Treasury as to when government guarantees would most likely be sought.

Alternatively, the government could undertake to recapitalize the CB should its capital fall below a given threshold or turn negative. In such a scenario, the CB could take the risk of any losses that arise from the liquidity operation up to the point where its capital falls below a predetermined level. Providing a general undertaking in itself is not sufficient, as there are instances where the sovereign has agreed to undertake the recapitalization, but with no exact period for completion being prescribed. Importantly, any recapitalization of a CB should be performed by way of marketable securities, carrying market rates of return, and ranking pari passu with other government obligations. (There have been cases of CBs, including in Europe and the Middle East, where long-term government securities with low rates of return and sometimes limited tradability have been used, but with a net present value far below the level required for recapitalization.) In principle, any losses associated with the provision of LOLR could be made good over time through the retention of all, or a portion of, future profits to be distributed to the State. ${ }^{69}$ While the retention of profits could continue until CB capital buffers are restored, future profits may be uncertain; indeed, some CB balance sheets suggest that any profits in the foreseeable future are unlikely.

However, for financial stability reasons, the prospect of recapitalization may have to suffice. Credit rating agencies are increasingly focusing on the contingent liabilities associated with public sector support. The provision of an indemnity could be credit negative for a country, possibly resulting in an increased cost of market funding, or at an extreme, a loss of market access, which could put the public debt on an unsustainable path. ${ }^{70}$ Some possible competition issues associated with fiscal guarantees are discussed in Section VII.

\footnotetext{
${ }^{66}$ In some jurisdictions, debtor notification and/or approval may be required before the loan assets can be used as collateral with the $\mathrm{CB}$; in others, local custom may make it practically impossible to take possession of residential property collateral.

${ }^{67}$ Prepositioning of collateral—as done for instance for the U.S. Federal Reserve's "Discount Window" access (though this is not a LOLR facility) - allows the CB time to examine documentation and conduct any necessary valuations before the collateral is used.
} 


\section{Supervisory Response-Domestic Institutions}

Increased supervisory intrusion and conditionality is a necessary prerequisite in any provision of bilateral LOLR. The supervisor should enhance supervisory oversight and adopt early intervention measures as required. The supervisor's powers should allow it to impose prompt corrective actions when certain counterparty actions are not met. Such conditionality could include asset sales, a bar on distribution of profits and payment of bonuses, changing management, and other measures to address governance and risk management failures. ${ }^{71}$

As noted earlier, individual institutions that receive bilateral LOLR should be subject to a binding funding plan, drawn up at the earliest opportunity between the $\mathrm{CB}$ and/or supervisory authority, and the institution. This plan should project the assets and liabilities of the counterparty going forward, at least one year out, and include anticipated roll off from the counterparties asset portfolio, upcoming bond and interbank redemptions along with anticipated deposit flows. The plan should be updated on a regular basis and include a number of stress assumptions, such as (where relevant) assumed flows stemming from a rating downgrade, assumptions regarding roll-over rates of deposits, interbank activity and bond maturities. ${ }^{72}$ In addition, the $\mathrm{CB}$ and regulatory area/authority should engage at least on a daily basis with the bank to ascertain if there are any unanticipated liquidity strains or any additional warnings of bank fragility and receive daily or intra-daily liquidity updates.

It may also be necessary to impose some conditionality on the entity to ensure that it stays in line with its funding plan. Remedial actions may include binding requirements for deleveraging, asset and liability transfers along with other forms of restructuring. Conditionality may also involve administrative measures such as forbidding the paying of dividends to shareholders and a say on increases in staff salaries. The institution should be mandated to use the liquidity provided only for its core business, such as honoring

\footnotetext{
${ }^{68}$ Should the CB request additional support by way of a government indemnity, the provision of LOLR then becomes a joint responsibility with the fiscal authority.

${ }^{69}$ It is worth noting that flexibility on the retention of profits is not possible for all CBs; in many cases precise profit distribution conditions are stipulated in legislation.

${ }^{70}$ For example, the U.S. support for state-sponsored enterprises was not seen to impact the U.S.' AAA rating (see Cebotari (2008), p. 3); on the other hand, the Wall Street Journal quotes Moody's explanation of their five notch downgrade of Ireland (in 2010) as being due to "the repeated crystallization of bank-related contingent liabilities on the government's balance sheet". See: www.wsj.com.

${ }^{71}$ It would be expected that the recipient institution would not engage in activities beyond its core functions without prior CB approval.

${ }^{72}$ Such flows could include the potential loss of CB repo eligible collateral, cash triggers in securitized products and derivative related margin calls, resulting from, for example, rating downgrades.
} 
previously-granted overdraft facilities, and not to extend non-core or risky lending. ${ }^{73}$ As cash and securities are fungible in their own right, it is not practical to track all liquidity provided. However, close attention should be paid to significant changes in the composition of the bank's asset portfolio.

LOLR operations should not be used for capital management exercises such as debt buybacks. The LOLR funds could in any event be used to meet debt repayments as they come due. However, while meeting maturing debt payments is a liquidity issue, calling debt ahead of term should be considered a capital management technique, whether it is repaid at par (bailing out bondholders rather than protecting financial stability) or at less than par.

\section{E. Supervisory Response-Cross-Border Banks}

Increased supervisory intrusion and conditionality may not be straightforward in the case of cross-border entities. Subsidiaries are entities which are legally separate from the parent, while branches are extensions of the parental legal entity. In many jurisdictions branches can operate in a "host" country under the authority of a license from, and supervision by, the "home" authority, while subsidiaries are supervised by the country in which they are established. As the 'host' authorities are not the supervisor, they may lack the information needed to assess the financial position of the parent or the detailed position of the branch, as well as intervention powers. In such instances, and in the absence of appropriate coordination mechanisms including an MOU with the "home" supervisor, it is not clear that the 'host' country should provide LOLR. In the main, there are two risks associated with lending to entities which form part of cross-border groups. ${ }^{74}$

\section{Up-streaming of funds in the case of branches}

The risk of up-streaming arises when funds provided by the home CB to the local entity are passed on to the head office in another jurisdiction. The host CB may not be in a position to assess the liquidity position of a local branch or the foreign parent of the entity. In addition, the host authorities may lack the ability to impose early intervention measures effectively, should the bank's actions not be in line with expectations, and it up-streams funds to the parent or other group entities. In this case, LOLR may fail to address the problem faced by the host $\mathrm{CB}$, since no protection would be provided to domestic creditors of the distressed bank.

\footnotetext{
${ }^{73}$ Indeed, controls may be needed even before LOLR is provided. For example, the authors are aware of cases where a bank that was put into administration had expanded its balance sheet substantially despite regulatory concerns.

${ }^{74}$ There is also the risk that centralized collateral management within the group may make it difficult to identify, from a legal perspective, which entity within the group has title to that collateral. This risk should be removed before the $\mathrm{CB}$ extends liquidity.
} 


\section{Risk that the parent no longer supports the local subsidiary}

The liquidity need could stem from the parent stopping support for the local entity. This could be a result of a number of factors, including concerns about the quality of the local entity's balance sheet, local currency depreciation or sovereign debt restructuring. But it may also reflect weakness in the parent: for example, in 2010-11 Greek banks operating in Bulgaria and Romania faced liquidity problems when the parents required LOLR support. Since the reputational risks of allowing a subsidiary to fail could be very damaging for the group, such a scenario is only likely to unfold when the parent and group are also under severe distress. ${ }^{75}$

\section{Methods by which central bank risks can be mitigated}

The host CB may not be the only source of liquidity for subsidiaries and branches. For example, the parent company may be in a position to support the entity, possibly using liquidity provided by the home $\mathrm{CB}$. The HKMA makes such an assumption when considering LOLR to branches of foreign banks. In very limited circumstances the HKMA may lend to branches of foreign banks; (i) by swapping Hong Kong dollars for U.S. dollars held by the branch if no suitable market counterparty can be found and (ii) the provision of bridge finance to a branch when the HKMA has confirmation that the provision of liquidity from the parent is forthcoming. This option becomes particularly relevant should the collapse of the subsidiary or branch create financial stability concerns for the home authorities.

Nonetheless, should the decision be taken by the "host" CB to lend in response to a systemic risk, it is prudent that the following be established:

- $\quad$ Evidence from the parent that alternative funding cannot be sourced from other parts of the banking group or from the home CB.

- $\quad$ An MOU between the home and host CB (or supervisory authority) for the sharing of prudential information so that the financial position of the branch and the banking group can be fully assessed by the host authorities as and when required.

- A determination that the foreign bank operation is systemically-important in the host jurisdiction.

In case of provision to foreign-owned entities, terms, and conditions should be attached to LOLR which allow for full oversight and sanctions over the recipient for non compliance e.g., with respect to intra-group transactions. Such measures could include ring fencing the assets and liabilities of the local institution (i) to prevent the relocation of high quality assets

\footnotetext{
${ }^{75}$ As with the 2008 failure of the London subsidiary of Iceland bank Kaupthing (see Johnsen, 2014).
} 
to the parent; (ii) to ensure the liquidity provided remains within the jurisdiction; and (iii) to avoid the need for further liquidity provision by the "host" CB.

\section{F. Foreign Currency Lender of Last Resort}

The provision of LOLR in foreign currency may be needed when the financial system is "partly-dollarized, or because the financial sector is reliant on cross-border FX funding. Emergency lending has been provided only in domestic currency, in line with the premise that commercial banks should themselves be responsible for management of foreign currency risk in many emerging and developing countries with relatively high levels of financial dollarization. However that premise has not been valid for several years. ${ }^{76}$ This became evident during the GFC, when large exposures of some banking sectors to foreign currency risk, combined with the sudden global tightening of FX liquidity, required some CBs to go beyond their usual practice in order to restore confidence and liquidity in their domestic markets. Such support will normally be limited, as a CB has only a limited supply of FX (not all of which may be readily available). In general, the provision of FX LOLR during the GFC was conducted in response to systemic need, rather than on a bilateral basis.

Meeting the FX liquidity needs of banks becomes particularly problematic when the CB has limited or no available FX resources to provide such lending. This applies particularly to countries with a high level of financial dollarization or under currency board regimes, whose prevailing monetary regime or (finite) FX asset holdings may restrict the CB's ability to respond to FX liquidity needs. While some CBs entered into currency swap agreements during the recent GFC to meet systemic needs for FX liquidity, not all CBs were able to benefit from such support: some had to make use of their own FX reserves. ${ }^{77}$ The IMF is now including consideration of the potential need for FX LOLR when estimating the appropriate level of official FX reserves that a country should hold (see IMF, 2015). For fully "dollarized" countries, consideration could be given to earmarking government funds for bilateral LOLR support (e.g., Kosovo). In other cases, the authorities are exploring the creation of a dedicated contingency fund financed by banks.

Policy measures should be considered to reduce the risk of a systemic or idiosyncratic foreign currency liquidity need. The supervisor could consider tightening FX prudential liquidity requirements as FX risk grows, and in any case should monitor liquidity mismatches broken down by major currency groups, ideally also identifying cross-border exposures. The macro-prudential authority could consider macro-prudential measures to limit the buildup of FX vulnerabilities, such as system wide limits (for example as a percentage of capital) on FX

\footnotetext{
${ }^{76}$ See for example, Reinhart et al (2014).

${ }^{77}$ Some 14 CBs borrowed USD via currency swaps with the Fed, and some European CBs engaged in swaps and repos with the ECB.
} 
loans to un-hedged borrowers, or levies on FX deposits. ${ }^{78}$ If not adopted, or if they prove inadequate to prevent an FX liquidity need arising, the following preparatory steps could be taken by a CB before it provides bilateral LOLR in FX. ${ }^{79}$

- $\quad$ The CB should quantify the scale - and currency denomination — of the likely FX currency need by examining the balance sheets of the banks and assuming e.g., a non rollover of X percent of short-term FX liabilities. This need should then be matched against currently available FX resources, including official FX reserves and any existing currency swap lines with other CBs or international authorities. ${ }^{80}$

- $\quad$ The CB should investigate (realistic) options to increase the availability of FX. For example, there may be scope for the CB to increase existing, or establish new, currency swap lines with other CBs or other international authorities. ${ }^{81,82}$ The CB could also consider possible mechanisms to incentivize the foreign parent bank to provide (or at a minimum maintain) the necessary FX funding to its subsidiaries and branches.

- The authorities might consider quantitative restrictions on the amount of FX support, if any, that banks can obtain from the CB. Constraints could be formulated in various ways: explicit, hard limits, expressed as a function of the bank's size (e.g., a fraction of total liabilities); or implicit limits which are defined internally and used as guidance in crisis situations. Announcing limits would (deliberately) restrict the ability of the CB to respond to particular situations, and may not be time consistent in practice. It may be better simply to announce that the provision of FX liquidity would be restricted (without specifying the limits) and only made under exceptional circumstances.

\footnotetext{
${ }^{78}$ In many countries, only domestic-currency deposits benefit from deposit insurance; and even when foreign currency deposits are covered, payouts are typically in domestic currency.

79 The same considerations could hold when meeting a systemic need for FX liquidity is being considered. However systemic FX liquidity needs may reflect macro economic imbalances within the economy which may need to be addressed through a wider policy response.

${ }^{80}$ However, FX swap lines may not prove a sufficient or efficient substitute for the accumulation of FX reserves, as they are conditional and time-bound, and many CBs do not have access to them.

${ }^{81}$ To ensure that swap lines are available when called upon, it is preferable for CBs to enter into swap arrangements with international authorities or central banks, rather than with private institutions.

${ }^{82}$ For some CBs this could also involve seeking access to government FX holdings normally reserved for FX intervention, rather than for financial stability/liquidity provision purposes.
} 
- $\quad$ As a last resort the CB may also need to carefully consider the imposition of administrative controls. Such measures could entail ring-fencing FX deposits, deposit conversion or deposit restrictions. A number of $\mathrm{CBs}$ have used such controls when faced with a potentially large drain on limited FX reserves. However, given the potential financial stability implications associated with these measures, any introduction should only be considered when other possible avenues have been exhausted.

\section{Key Outstanding Challenges}

\section{A. Central Bank Autonomy}

An important principle is that CBs do not assume risks in their LOLR operations so large that - if realized - would undermine public confidence. Moe (2012) notes the threat of a loss of confidence and lack of public backing that can result from substantial losses (p. 31). Some CBs are now taking the opportunity to review their emergency arrangements and be more prescriptive as to when they can intervene, in order to ensure an appropriate balance between financial stability and CB autonomy (IMF, 2014). When doing this, it will remain important that $\mathrm{CBs}$ retain some element of discretion, given the level of judgment and unpredictability involved in emergency interventions (Winters, 2012).

It is not clear ex ante how much a $\mathrm{CB}$ can risk losing without bringing into question its independence. But if the sovereign — with "long-run deep pockets"-is unable or unwilling to take on the burden of or provide an indemnity for LOLR, it is not clear that the CB-with only "short-run deep pockets" - can do so without endangering long-run financial stability.

\section{B. Competition Policy}

The provision of idiosyncratic liquidity support involves the use of public funds, and in certain circumstances could be seen as a function of the state rather than the CB. A company that receives state support (e.g., through receipt of a government guarantee, or LOLR funds) could gain an advantage over its competitors, as it would allow the bank to secure 'cheaper' funding than would otherwise be available, and potentially thereby avoid its own exit from the market. For such level playing field reasons, competition rules may come into play in the case of LOLR provision. However, competition laws or compliance processes which entail long decision making horizons or do not take wider public policy interests into account could undermine the effectiveness of LOLR e.g., if it cannot be deployed quickly enough to stabilize the entity and stem the risk of contagion.

In Europe, the European Commission is charged with ensuring state aid complies with EU law. The Commission's approach, which evolved during the crisis, allows for an interpretation that LOLR granted at the CB's initiative, at a suitably high rate and to illiquid 
but fundamentally solvent entities, is not state aid ${ }^{83}$ However, CB lending to potentially insolvent entities, or which is under-collateralized and/or is indemnified by the state, is considered state aid and could trigger a formal and lengthy proceeding by the Commission. ${ }^{84}$

Given the high economic cost of systemic financial crises, authorities should ensure that competition policy frameworks do not overly restrict the CB's ability to provide LOLR flexibly. In particular if competition rules do apply, exemptions and accelerated procedures should be in place for cases in which financial stability is threatened.

\section{Public Banks}

While in principle public banks should be eligible for LOLR operations, particular attention should nonetheless be given, on an ongoing basis, as to why alternative sources of liquidity are not available to them. In some circumstances, it may be preferable for the sovereign, in times when it does not have easy access to capital markets, for the CB to provide lower-cost (but no lower than any LOLR provided to private sector banks) bilateral support to the concerned publically-owned institution. Such an approach may benefit the government in at least two ways. Firstly, the costs associated (or at least a portion thereof) with this lending will most likely be passed back to the government, but with a delay, in line with agreed (profit redistribution) protocol. Secondly, when government sources of funding are limited, the fiscal authorities may have a preference for state-owned banks to be funded by the CB rather than have the institution competing in private funding markets (and therefore with treasury funding).

\section{SUMmary AND CONCLUSIONS}

Central banks' approaches and practices regarding the provision of LOLR vary considerably, in significant part as a result of responses to the GFC. While the classical view is that LOLR should support temporarily-illiquid but solvent banks, both the financial and regulatory environment have come a long way since the days of Bagehot's Nineteenth-century "Lombard Street." The application of the Bagehot principles to a new financial world, at an operational level, have proven to be particularly complex.

This paper has argued that:

- $\quad$ There are instances where the provision of LOLR funds to some non-banks is warranted, but careful consideration needs to be given to the reasons for doing so and

\footnotetext{
${ }^{83}$ Psaradoukakis (2012). Regarding the EU Commission's actual approach, please see in particular Chapter 5 of their "Banking Communication" available at http://eur-lex.europa.eu.

${ }^{84}$ In its evolving practice during the crisis, the EU Commission sought to avoid opening formal proceedings and instead take a quick decision by requiring suitably severe commitments (including divestment of assets) from the recipients which allowed it to conclude that the aid did not raise serious competition issues.
} 
the way in which the support is structured. Idiosyncratic LOLR for NBFIs is unlikely to be appropriate, except in the case of systemically-important CCPs. As a contingency, CBs may benefit from having statutory powers in place to lend to regulated and supervised NBFIs in exceptional circumstances. If the exceptional liquidity demand of non-banks has arisen as a result of market inefficiencies or regulatory loopholes, policies should be put in place to limit or prevent these arising again in the future.

- $\quad$ System-wide problems in NBFIs may also justify a system-wide response to prevent asset fire-sales, which may have damaging consequences for financial stability. Tackling asset fire-sales is a difficult task and will most likely involve the CB (or government) accepting additional risk. Non-recourse lending (or, possibly, the sale of out-of-the-money put options) may offer an effective tool to address these problems without creating excessive moral hazard. But this is not market making, in the sense of making a two-way price and expecting to trade in both directions: the authorities are more likely to become "buyer of last resort" and-if so-should be clear that this is the case.

- $\quad$ Solvency requirements remain a key component of LOLR when applied on a forward looking basis, and should complement the viability assessment of the institution. There is a strong argument to be made for lending to all regulated banks which are judged not to be insolvent, are able to provide collateral and - importantly-are seen as viable. But a business which is not viable should be wound down, even if it is solvent today.

- While LOLR support is intended to be temporary, the use of published time bound maturity limits can "tie the hands" of a CB in an unhelpful way. It proposes that the maturity of LOLR support only be as long as the underlying liquidity need, while the counterparty should at all times demonstrate a credible prospect of repaying the operation on or before maturity.

- $\quad$ An appropriate balance has to be found in terms of pricing, both the interest rate and any fees: the cost should be high enough to encourage banks to seek other forms of funding — including obtaining additional capital — but not so high as to exacerbate liquidity strains and make survival of the institution (and repayment of LOLR) less likely.

- $\quad$ Regulatory intervention and conditionality may be seen as an important element of the costs imposed on LOLR beneficiaries. Effective regulatory intervention and conditionality may be difficult in the case of NBFIs, and also foreign branches or subsidiaries of foreign banks.

- $\quad$ The ability to provide FX liquidity is an important safety net in many markets. For the majority of CBs, their ability to meet FX liquidity needs will be constrained and this 
should be clearly communicated to the market. Prudential or macroprudential measures may have a role in reducing potential FX calls, but are unlikely to eliminate them entirely. 


\section{APPENDIX I. OVERVIEW OF SYSTEMIC AND IDIOSYNCRATIC RESPONSES TO THE GLOBAL Financial Crisis in the Three Major Central Banks}

When the GFC broke, three major CBs (the U.S. Federal Reserve, the ECB, and the BOE) responded by increasing the supply of reserve money to meet a liquidity need - and only later on by cutting their policy rates (in many cases close to the zero lower bound) in response to monetary policy needs. They adopted a series of unconventional monetary policy actions in response to systemic and idiosyncratic liquidity needs.

\section{Counterparties}

Some CBs permitted existing counterparties to access new facilities, or expanded their counterparty lists. In an effort to address the non-functioning of certain parts of the financial market during the GFC, the U.S. Federal Reserve added to its OMO credit instruments by creating the Term Auction Facility (TAF), available to all depository institutions, which previously only had access to the Primary and Secondary Credit Facilities (PCF and SCF), known jointly as the 'Discount Window', and the maturity of the PCF was extended. ${ }^{85}$ The Primary Dealer Credit Facility (PDCF) was created for securities dealers, which previously could only participate in OMOs. Under the terms of Section 13.3 of the Federal Reserve Act, a line of credit was also extended to a non-bank subsidiary of AIG (an insurance company), and support was also provided to certain other non-banks (though all of these facilities were terminated once the markets stabilized). More recently, the BoE put in place arrangements to extend its monetary policy framework beyond banks to certain central clearing counterparties and particular broker dealers. ${ }^{86}$ The ECB has since its creation engaged with a large number of eligible credit institutions and did not expand its counterparty framework during the GFC.

\section{Instruments}

The most notable development was the establishment of the U.S. Federal Reserve's bilateral swap lines with some developed-country and emerging-market CBs. In December 2007 the Fed announced reciprocal currency arrangements with a number of $\mathrm{CBs}$, designed to provide dollar liquidity to overseas markets. Ultimately, lines were authorized for fourteen foreign CBs. The swap lines allowed the non-U.S. CBs to supply their domestic financial markets on a temporary basis with potentially unlimited quantities of dollars. The swap lines followed the principle that the home $\mathrm{CB}$ should be providing liquidity to banks under its own jurisdiction, and against domestic collateral, given that it has better information about the borrower's needs and prevailing financial conditions (Committee on the Global Financial

\footnotetext{
${ }^{85}$ Indirectly, through the primary dealers, Asset-Backed Commercial Paper Money Market Mutual Fund Liquidity Facility (AMLF) made liquidity available to investment banks, broker-dealers and mutual funds.

${ }^{86}$ See the BOE's "Red Book" available at http://www.bankofengland.co.uk. Some non-banks have had access to the BOE's OMO for some years, but not to credit facilities.
} 
System (CGFS), 2008). A number of other bilateral FX arrangements were also initiated in response to the GFC, including a bilateral swap between the Central Bank of Ireland and the BOE. ${ }^{87}$

Operations were also introduced to provide the banking system with liquid assets, but without the need to create more reserve money balances. Both the U.S. Federal Reserve (Term Securities Lending Facility (TSLF)) and the BOE (Special Liquidity Scheme (SLS)) swapped illiquid assets (for which the private market was shut) against treasury securities.

Some instruments targeted the demand for longer-term liabilities. The ECB announced a fixed-rate full allotment OMO policy in September 2008 and later extended the maturity of some operations to three-year operations (LTROs), to provide certainty of funding to the banking system. Some Eurosystem CBs also had to respond to idiosyncratic emergency liquidity needs at their own risk (see Bindseil (2014), p. 247). ${ }^{88}$

\section{Collateral}

Since 2008, both the BOE and ECB have expanded their collateral framework on a number of occasions, accepting assets not previously eligible, either in terms of asset type or credit quality. More recently, the BOE announced that in order to "enable greater dynamism in financial markets", it would offer funds for longer periods indexed to the policy rate, lower the cost of using the Bank's facilities (most significantly in relation to the use of lower quality collateral), and accept a wider range of collateral, including "any asset of which we are capable of assessing the risks." 89

\footnotetext{
${ }^{87}$ This arrangement was conducted through the ECB; for further details on this along with an overview of all foreign currency liquidity providing swaps entered into by the ECB, see ECB (2014).

${ }^{88}$ For a description of the responsibilities around the provision of bilateral LOLR support within the Eurosystem see ECB (2013).

${ }^{89}$ See Carney (2013).
} 


\section{APPENDIX II. DESIGNING A FRAMEWORK}

\section{A. Interaction with the Market}

\section{Ex ante disclosure}

There are two general approaches that CBs can take to describe their idiosyncratic response framework to market participants. ${ }^{90}$

- Under a "rules-based" approach, ${ }^{91}$ the CB explicitly states to the market its requirements and the operational parameters for LOLR. These disclosures can cover (i) the preconditions for emergency lending; (ii) the CB's discretion to lend; (iii) the terms and conditions of emergency lending, including tenure, eligible collateral, and pricing; and (iv) remedial actions and supervisory response. There are a number of benefits to a "rules-based" approach, including that it may condition market counterparts behavior e.g., to maintain prudent levels of unencumbered LOLR eligible assets on their balance sheet, and may help reduce pressure on the $\mathrm{CB}$ to extend LOLR to ineligible entities e.g., if they are not viable or insolvent. However, the more detailed and prescriptive the framework, the greater the risk that it will prove "time inconsistent". In the face of systemic pressures, the CB may have to extend LOLR on terms that do not comply with the disclosed framework, or can establish "cliff effects". For example, if LOLR is limited to a predefined cap, such as a fixed ratio of certain balance sheet items, this could exacerbate creditor runs. ${ }^{92}$

- Under a "constructive ambiguity" approach, ${ }^{93}$ the pre-conditions and operational arrangements are not (fully) disclosed. While being less transparent and lacking the benefits of a rules-based system, this approach allows the CB more freedom in tailoring its framework as the situation requires. Even if not publically disclosed, it is strongly recommended that risk management policies and operational procedures be documented internally.

\footnotetext{
${ }^{90}$ See He (2000).

91 This approach is used in countries such as Hong Kong (policy statement), Montenegro (Board decision) and Bank of Canada (guidance note).

${ }^{92}$ Moreover, given the possible wider systemic risks at play, the decision not to support an institution over and above an "arbitrary" threshold may be difficult to defend in any ex post assessment conducted.

${ }^{93}$ Constructive ambiguity - access to CB liquidity assistance is uncertain, something that is determined ad hoc in each situation (He, 2000). This approach is used in Eurosystem countries, Russia, New Zealand, and Norway, to name a few.
} 
Table 2. Disclosure: "Rules-based" Versus Ambiguity

\begin{tabular}{|l|l|l|}
\hline Central Bank Stance & \multicolumn{1}{|c|}{ Pros } & \multicolumn{1}{|c|}{ Cons } \\
\hline "Rules based" & $\begin{array}{l}\text { Transparent, clear, and } \\
\text { understanding by the market } \\
\text { of the rules. } \\
\text { Condition market behavior. }\end{array}$ & $\begin{array}{l}\text { May be too restrictive with no ability } \\
\text { to adapt at short notice. } \\
\text { May not stay in touch with financial } \\
\text { innovation and collateral } \\
\text { developments. } \\
\text { Could be seen as a funding pre- } \\
\text { commitment. }\end{array}$ \\
\hline $\begin{array}{l}\text { "Constructive } \\
\text { ambiguity" }\end{array}$ & $\begin{array}{l}\text { Can be as responsive as the } \\
\text { particular situation requires. } \\
\text { Avoids disclosing limits which } \\
\text { may amplify the situation as } \\
\text { participants rush to withdraw } \\
\text { funds from the concerned } \\
\text { bank. } \\
\text { The market is not aware when } \\
\text { a situation becomes } \\
\text { particularly acute. }\end{array}$ & $\begin{array}{l}\text { Lack of transparency may bring into } \\
\text { question the influence of outside } \\
\text { Taxpayers may demand the right to } \\
\text { know the exact details surrounding } \\
\text { the provision of public money. }\end{array}$ \\
\hline
\end{tabular}

Source: IMF Staff.

Overall, general advice would be that when a CB is designing its LOLR framework, it should not overly restrict their ability to respond to particular circumstances. Every case of LOLR will present different risks and some flexibility should be maintained e.g., published limits on the amount of LOLR support that may be provided can be problematic from a time consistency perspective, and may risk destabilizing effects. CBs not following a "rulesbased" approach could consider disclosing key aspects of the LOLR framework, without making any pre-commitment to lend. These might include the approach to determining solvency/viability tests, and categories of assets that may be acceptable etc., so that the market is well informed and can make its own contingency planning arrangements.

\section{Ex post disclosure}

For many years, CBs disclosed little information or explanation, if any, about their LOLR operations, but there is increasing pressure for disclosure. It was often felt that the most efficient provision of bilateral LOLR is when "no one knows about it", given that the health of the financial institutions depends importantly on public confidence. Providing information on liquidity support concurrently with its advance may confirm existing creditor concerns about potential failure and exacerbate the situation by accelerating deposit runs on the bank. ${ }^{94}$

\footnotetext{
${ }^{94}$ In the U.K., the information on liquidity support to Northern Rock precipitated a retail deposit run. This was stopped only after the announcement of a government guarantee.
} 
As the $\mathrm{CB}$ is using public resources to provide bilateral LOLR, ex post disclosure is needed to ensure adequate accountability. ${ }^{95}$ It is vital that the $\mathrm{CB}$ provide proof to the public that the actions undertaken were within current rules and within the CB's mandate, and that the CB operated in a competent manner throughout the process. More specifically, Bulir et al. (2014), citing the work of others, note that communication by various CBs (such as the U.S. Federal Reserve, the BOE, and the ECB) is relevant for financial markets, where "greater clarity has gone hand in hand with lower volatility in markets for various financial instruments" (p.3). The CB should undertake an ex post assessment of its LOLR operations with the aim of assessing how responsibilities were discharged and providing recommendations for further improvement.

Careful consideration should be given to the timing of the disclosure and the nature of the information disclosed. Best practice is for disclosure relating to the extension any bilateral LOLR to occur on an ex post basis. While it is generally the case that the names of institutions should not be disclosed, an appropriate time-lag is nonetheless needed as disclosing the information too soon could undermine the CB's policy objectives. ${ }^{96}$

Whether to sterilize LOLR or not is very much dependent on policy objectives and risks at the time. In the case of bilateral LOLR the reserves created flow quickly to "good" banks, and the excess reserve balances held by them may depress short-term interest rates. ${ }^{97}$ If this reduction in short-term rates does not coincide with monetary policy goals, then the CB may need to sterilize the excess, ${ }^{98}$ although sterilization operations may highlight the provision of the LOLR. ${ }^{99}$ In the case of the Eurosystem, while operating under a structural liquidity

\footnotetext{
${ }^{95} \mathrm{CBs}$ have many means of communicating with the market after the event, through its annual report or regular economic reviews, or public speeches. The annual report, because it is issued at a lag, more than the interim statements, provides an opportunity to clarify if emergency liquidity has been extended, through a note to the accounts, or in an explicit statement.

${ }^{96}$ Some CBs have policies relating to the disclosure of their emergency operations. For example, see Plenderleith (2012) on the BoE's delayed disclosure of LOLR to RBS and HBOS, for more than a year. The Dodd-Frank Act introduced a new mechanism of delayed disclosure where loans received under the U.S. Federal Reserve's regular discount window or through OMOs would be disclosed approximately two years after the operation, while operations conducted under 13.3 of the Federal Reserve Act would be disclosed one year after authorization for the facility has terminated.

${ }^{97}$ If the additional reserves are created in response to a systemic shock, the CB would generally not sterilize the operation since this would defeat its purposes.

${ }^{98}$ In the case of such asset swaps, there is no creation of reserve money, and so there is no need to sterilize.

${ }^{99}$ However, it may be possible for $\mathrm{CB}$ to explain to the market the rationale behind the idiosyncratic action in fact it could be explained as a regular action. For example, a CB could outline to the market that through its monetary policy framework it aims to maintain smooth market conditions and a fall in market rates below its policy target has necessitated the need for the sterilization operation.
} 
deficit, the introduction of the three-year LTROs (a systemic response) meant that reserves provided were well in excess of those actually demanded by the system as a whole. ${ }^{100}$ In this case, there was no urgent requirement to absorb additional liquidity provided by national CBs in response to idiosyncratic needs, as the ECB wanted at the same time to ease monetary conditions. ${ }^{101}$

\section{Disclosure and issues of stigma}

"The stigma attaching to a bank needing to resort to [bilateral LOLR] is an important safeguard against moral hazard" (Plenderleith, 2012, p. 75) ${ }^{102}$ However, it is important that any perceived stigma should not be so strong that the policy response is ineffective. CBs should aim to provide a level of comfort to sound counterparties so that in the event that they face temporary liquidity pressures they should be unrestricted in approaching the $\mathrm{CB}$ for liquidity support, although — as mentioned earlier — it should not be seen a right of access. In addition, and to the extent possible, the participating institution should have certainty around the operation in terms of confidentiality and disclosure policy: institutions should be comfortable with the fact that they will not be "named and shamed." However, on this latter point it may not always be possible to disguise the fact that use has been made of bilateral LOLR from the market, and this in turn may engender a "witch hunt" within media circles. ${ }^{103}$ While the focus of this paper is on the provision of LOLR to individual institutions, Appendix IV discusses further the use of OMOs as a means of possibly reducing stigma.

\section{B. Stakeholder Coordination}

\section{Establishing roles and responsibilities}

CBs have operational responsibility for the provision of LOLR support - to the extent such support requires the provision of $\mathrm{CB}$ money — due to their monopoly over reserve issuance

\footnotetext{
${ }^{100}$ Moreover, in some countries during the GFC the systemic need for extra reserves balances were not required as much as an additional source of term funding. In such cases, term lending operations balanced by short term sterilization instruments can be combined to keep market rates in line with the policy target.

${ }^{101}$ Under Eurosystem accounting rules there is no specific requirement for the provision of idiosyncratic liquidity to be specifically 'labeled' in the CB's accounts.

${ }^{102}$ Stigma concerns can also exist for regular monetary policy operations (see Winters, 2012). Regulatory, disclosure, or other consequences can prevent sound counterparties from accessing standard monetary policy operations.

${ }^{103}$ Plenderleith (2012) provides an interesting example “...in August 2007 Barclays used the Standing Lending Facility for purely operational reasons and journalists contacted U.K. banks the following day to find out which bank did not deny usage. The story of Barclays' use of the facility ended up on the front page of the Financial Times and acted to stigmatize the facility" (p33).
} 
within its own jurisdiction. Moreover, given their interaction with the market place through their regular monetary policy operations along with its familiarity with the operational aspects associated with the provision of collateralized lending (though not all CBs regularly engage in lending), the $\mathrm{CB}$ operationally is best suited to handle the provision of this lending. ${ }^{104}$

The principles and procedures for responding to idiosyncratic distress should be explicitly described in regulations or agreed internally among all stakeholders. Well-designed rules and agreed operational procedures for LOLR support defined ex ante among stakeholdersnamely, the CB, the treasury, domestic, and foreign supervisors - can permit the authorities to act swiftly, when required. ${ }^{105}$ In addition, documented rules and procedures help limit the risk of political pressure on the $\mathrm{CB}$, where the $\mathrm{CB}$ may be directed to lend, at its own risk, to entities or against collateral it would not otherwise be prepared to do.

\section{Table 3. An Example of Stakeholder Coordination}

\begin{tabular}{|l|l|}
\hline \multicolumn{1}{|c|}{ Task } & \multicolumn{1}{c|}{ Responsibility $^{106}$} \\
\hline $\begin{array}{l}\text { Scale of LOLR requirement and overview of } \\
\text { recent liquidity developments. }\end{array}$ & Supervisor \& Market Operations Area. \\
\hline Assessment of systemic impact (where relevant). & Supervisor (L) \& Market Operations Area. \\
\hline Good governance assessment-'fit and proper'. & Supervisor (L) \& Market Operations Area. \\
\hline Solvency \& viability assessment. & Supervisor (L) \& Market Operations Area. \\
\hline $\begin{array}{l}\text { Collateral availability, eligibility assessment of } \\
\text { collateral pre-positioned, risk controls and } \\
\text { valuation. }\end{array}$ & $\begin{array}{l}\text { Market Operations Area (L), Legal and } \\
\text { Supervisor. }\end{array}$ \\
\hline Exit/funding plans and conditionality. & $\begin{array}{l}\text { Market Operations Area (L), Supervisor, } \\
\text { Legal. }\end{array}$ \\
\hline Preparation of mobilization agreement. & Legal (L) \& Market Operations Area. \\
\hline Communication. & $\begin{array}{l}\text { Communications Area (L), Fiscal Authority, } \\
\text { Supervisor, Individual Institution. }\end{array}$ \\
\hline Indemnity. & Market Operations Area and Fiscal Authority. \\
\hline Decision. & Central Bank Board. \\
\hline
\end{tabular}

Source: IMF Staff.

Relying on number of key areas — banking supervision, operations, legal — detailed LOLR planning and preparations will be required (see Table 3). CBs should ensure that their LOLR responses are swift and coordinated. This requires well-defined legal powers, processes, procedures, and clarity in the roles and relationships among all relevant internal and external

\footnotetext{
${ }^{104}$ Depending on the operational capabilities of the government and its familiarly with the deposit and repo markets, the government or other entities may request the $\mathrm{CB}$ - as honest broker - to carry out the operational aspects of these market solutions on their behalf.

${ }^{105}$ Some countries, such as the U.K., Denmark, and Australia have established MOUs.

106 Tasks are in no particular order. (L) indicates lead role.
} 
stakeholders. CBs should regularly perform testing of LOLR processes and also have in place reliable contingency operational arrangements. Moreover, CBs should establish an internal working group to facilitate the sharing of information, and formulation of procedure documents and testing schedules, which should allow all parties involved have a clear understanding of their respective roles.

Key reliance is placed on the supervisor so as to anticipate, assess, and monitor the liquidity need. As mentioned earlier, a key factor that distinguishes LOLR from other operations is the requirement for enhanced supervisory oversight and adoption of early intervention measures, as required. The supervisor best positioned to "look under the hood" of individual institutions and its involvement is crucial in a number of areas, such as the ex ante monitoring of the banks' funding flows, the assessment of adequacy and eligibility of collateral holdings and potential LOLR drawdown requirements; the determination of solvency and viability; the formulation funding plans upon which the ongoing provision of LOLR is dependent; and ex post compliance with these plans. ${ }^{107}$

The decision-making process, and risks associated with the lending, can also be retained by the sovereign. In the U.K., for example, financial stability is targeted through a Triparty MOU. This agreement divides responsibilities between the BOE, which contributes to maintaining financial stability and is in charge of the operational aspects of LOLR, the Prudential Regulation Authority, which has responsibility for regulating certain entities and promoting stability of the financial system, and the chancellor and treasury which has the sole responsibility for any decision on the provision of public funds. ${ }^{108,}{ }^{109}$ In certain circumstances, the BOE can provide certain lending outside of the BOE's liquidity provision framework, on behalf of the government, but is fully indemnified and its functions are also limited acting as the treasury's agent. ${ }^{110}$ For countries under currency board arrangements any provision of reserves by the $\mathrm{CB}$ is prohibited, except in the case where the $\mathrm{CB}$ has free reserves over and above the binding level of foreign reserves (typically 100 percent of base

\footnotetext{
${ }^{107}$ Depending on the institution at hand cross-border arrangements for cooperation, coordination, and exchange of supervisory information may also be required.

${ }^{108}$ See MOU between the Bank, including the Prudential Regulation Authority, and the treasury regarding Financial Crisis Management available at www.bankofengland.co.uk.

109 The authorities in the U.K. have not yet made clear if, following the recommendations made in the Plenderleith report, the risk associated with LOLR lending resides with the BoE or with the U.K. Treasury.

${ }^{110}$ Section 61 of the Financial Services Act 2012, allows the Chancellor to direct the Bank to "conduct special support operations for the financial system as whole, in operations going beyond the Bank's published frameworks" where "the Chancellor directs the Bank to conduct a support operation, either to the financial system as a whole or to one or more individual firms, the Bank will act as the Treasury's agent". See: www.bankofengland.co.uk.
} 
money). Absent these excess reserves, any provision of support to the financial system instead falls under the responsibility of the government (see Box 6). ${ }^{111}$

\section{Box 6. Examples of Funding Alternatives to Lender of Last Resort}

There are a number of alternative funding solutions that may avoid, or prolong, an LOLR requirement. For example:

Funds within the banking system may be pooled together, along with government liquidity support and in some cases CB support. This "rainy day fund" can be used to meet the illiquidity needs of qualifying institutions and can be administered by the $\mathrm{CB}$. An example would be the Korean liquidity support program for securities dealers in the GFC. ${ }^{12}$ There are also a number of least preferred alternatives, which would need to be carefully considered and implemented only in extremis:

- The government may undertake to guarantee the liabilities of a distressed institution, but excluding equity and subordinated debt instruments, and possibly some other liabilities. This could be undertaken while a more permanent solution for the entity is being devised, but should be collateralized (for example, by shares) and include a fee. The level of liquidity support needs to be thought through carefully by the authorities as guarantees create additional contingent liabilities which may, amongst other things, be credit negative and threaten market confidence. ${ }^{113}$ Moreover, a guarantee of a low rated country may not be sufficient to "defend" an institution from market speculation. A limited guarantee and a back up resolution plan may be required to manage these contingent risks. Significant moral hazard and fiscal risks do arise with the above strategy and that is why careful consideration is required before such a strategy is explored.

- The government may provide the required liquidity itself. This could be performed either directly as unsecured deposits (most likely in the case of a state institution where the counterparty risk is that of the state) or enter into collateralized repurchase agreements with the concerned institution. This requires the government to have available the necessary funds, while the placement of these funds should always be structured as a market transaction and be conducted with institutions complying with the government's own risk control measures. The rationale for the government providing such support also needs to be clear and the provision of such support should not be undertaken so as to avoid the enhanced supervisory intrusion, conditionality, or the prudent collateral policy measures that would otherwise apply to the CB's LOLR arrangement.

- Indirect lending could involve the provision of CB funds to eligible counterparties that directly on-lend the funds to concerned banks. The provision of such funding by the $\mathrm{CB}$ needs to be carefully configured so that the $\mathrm{CB}$ is not seen to interfere with individual institutions' independent risk assessment. These transactions should be performed on market terms and appropriate safeguards should to be in place to protect the intermediary institution against contagion and other risks, where at a minimum a government indemnity should be requested. An example of an indirect transaction took place in Ireland during the GFC. ${ }^{114}$

${ }^{111}$ See Reuters (2014) in the case of Bulgaria. In addition, in Hong Kong lending to institutions not meeting the preconditions for idiosyncratic emergency support requires specific approval from the Financial Secretary.

${ }^{112}$ See Presentation "Structural change in the corporate bond market in Korea after the currency crisis" by Sungmin Kim, The Bank of Korea, available at www.worldbank.org.

${ }^{113}$ In certain jurisdictions, such as within Europe, the provision of sovereign guarantees may create issues from a state aid perspective.

${ }^{114}$ See "Proposed securities repurchase transaction with Irish Bank Resolution Corporation" available at www.bankofireland.com. 


\section{APPENdiX III. COllateral AND Risk CONTROL Measures}

\section{Maybe not so "good" after all...}

As touched on in Section VI, the collateral presented for LOLR is more likely to be less liquid than "good." The following presents an overview of how CBs could approach issues such as; what collateral could be accepted, some of the collateral specific issues CBs should be aware of, along with some of the key principles around the formulation of appropriate risk controls and valuation methodologies.

Regular engagement with the financial system allows CBs to gain an understanding of the type of assets held and how these holdings might change going forward. More than likely, the CB will already have an understanding of counterparty holdings from the establishment of its monetary policy framework, but nonetheless it is good to stay in touch with counterparties and monitor developments in asset quality and lending practices. ${ }^{115}$

When deciding on the type of collateral to accept, the CB could consider which assets have the following traits: ${ }^{116}$

- Legal certainty - certainty in relation to the transfer of legal title or beneficial interest to the $\mathrm{CB}$ which ensures that in the event of a counterparty default, there are no impediments to the CB's ownership of the asset. Regarding loan portfolios, there is a lot of benefit in having the sample loan documentation examined by the CB's legal area to ensure that there are no embedded restrictions with regard to asset transferability. In addition, it is generally easier to mobilize collateral-particularly loan collateral — when it is governed by local law rather than foreign law, as the CB's claim may not always be recognized under foreign law. Any uncertainty about the ability to claim the collateral certainly inhibits its effectiveness as collateral.

- $\quad$ Central bank status - the CB should understand its status as an investor; for example, whether it is senior or subordinated in terms of the asset's principal and coupon payments or voting rights.

- $\quad$ Credit assessment - best advice is that CBs should, where possible, accept assets for which a credit assessment has been undertaken. This assessment can be performed by rating agencies or "off the shelf" products such as rating tools. For more advanced $\mathrm{CBs}$, the credit assessment function can be performed in-house.

\footnotetext{
115 This may be seen by some CBs as a reason to adopt a "constructive ambiguity" approach in relation to communication on its emergency idiosyncratic response framework, as this may make it easier for the $\mathrm{CB}$ to change, at a date in the future, the collateral it is willing to accept.

${ }^{116}$ See also Bindseil and Papadia (2009).
} 
- Ease of transferability - ability for the counterparty to transfer the asset quickly to the $\mathrm{CB}$, without over burdening and lengthy registrations or notifications (e.g., ex ante and/or ex post debtor notifications can slow down the process). Consideration could be given, during normal times, to standardizing loan documentation, for example, by introducing measures to overcome onerous restrictions, therefore allowing for the collateral to be transferred in a time efficient manner should the need arise.

- $\quad$ Ease of valuation - without deep and liquid markets, the CB may have to procure a valuation approach or develop one in-house which may take time to develop and may be costly.

- $\quad$ Ease of handling - the handling of loan collateral is not as straight forward as securities, which in the majority of cases are held in book entry form. For loans, adhoc and manual or sophisticated information technology systems may need to be developed to handle large volumes of loans. The CB's preference would be to avoid as much as possible accepting loans on an individual basis, as the operational and legal considerations involved in transferring each loan can be time consuming and complex. $^{117}$

- $\quad$ Effectiveness - LOLR is an emergency operation aimed at addressing the short-term liquidity needs of the distressed counterparties. Accepting only a narrow range of collateral limits the effectiveness of the LOLR response as the holdings of these assets across individual institutions may be small (although restricting normal collateral lists may give banks an incentive to hold some good quality collateral).

- Data availability - in the case of loan collateral, the CB should be aware of what data is available for the assets identified, e.g., geographic location, latest valuations, loan to value ratios, monthly repayment amounts etc, so that an appropriate assessment of the collateral can be made.

- No "close links"-Unsecured debt issuances or equities of parties closely related to that of the counterparty should not be accepted due to "double default" risk. "Close link" relationships could exist in certain securitized transactions and such risks can be mitigated. $^{118}$

\footnotetext{
${ }^{117}$ Common law frameworks allow for the mobilization of pools of loans under legal charge in favor of the assignee, which is legally complex under civil law.

${ }^{118}$ For example, within asset backed securities or covered bonds, the CB may look to limit the role of related counterparties through haircut add-ons or by requesting that adequate contingency arrangements be incorporated into the underlying documentation.
} 
- $\quad$ Diversification - ideally, the collateral identified should be diversified in order to prevent concentration risk.

\section{Table 4. Examples of Lender of Last Resort Collateral}

\begin{tabular}{|c|c|}
\hline \multicolumn{2}{|c|}{ Examples of assets that have the potential to be mobilized as LOLR collateral } \\
\hline Type & Issues to Note \\
\hline Corporate or bank securities & $\begin{array}{l}\text { "Close links" between the collateral and the counterparty } \\
\text { requesting LOLR (double default risk) would need to be } \\
\text { assessed. }{ }^{119} \text { Appropriate valuation in an illiquid market may } \\
\text { be difficult. }\end{array}$ \\
\hline Securitized assets & $\begin{array}{l}\text { Ideally, the underlying pool should be transparent and it is } \\
\text { best that the CB have a complete understanding of the } \\
\text { structure of the transaction, before it is accepted. As the } \\
\text { security pay down is dependent on the performance of the } \\
\text { underlying portfolio, appropriate valuation may be difficult. }\end{array}$ \\
\hline Residential loans & $\begin{array}{l}\text { Mobilization of large quantities of individual loans may be } \\
\text { cumbersome for the CB, from an operational, risk } \\
\text { management, and legal perspective. }\end{array}$ \\
\hline Commercial mortgages & $\begin{array}{l}\text { While individual commercial mortgages may be relatively } \\
\text { large, operational, risk management and legal issues will } \\
\text { arise for the } C B \text {, particularly as the loans can be based on } \\
\text { bespoke agreements. }\end{array}$ \\
\hline $\begin{array}{l}\text { Corporate loans and public sector } \\
\text { loans }\end{array}$ & $\begin{array}{l}\text { Mobilization of large quantities of individual loans may be } \\
\text { cumbersome for the CB, from an operational, risk } \\
\text { management, and legal perspective. }\end{array}$ \\
\hline Equities & $\begin{array}{l}\text { Consideration needs to be given to (i) appropriately valuing } \\
\text { the equities given the volatility of the asset; (ii) } \\
\text { understanding of the CB position (as shareholder) in the } \\
\text { event of default of the institution; and (iii) ensuring there is } \\
\text { "no close link" or double default risk between the equity and } \\
\text { the institution borrowing LOLR. }\end{array}$ \\
\hline
\end{tabular}

Source: IMF Staff.

In the case of loan collateral a number of key variables are important to establish. The CB should gather - at a minimum - information on the type of loan (residential, corporate etc.), loan performance (loan-to-value ratios) and credit quality of the loan (assessment by the originator or CB). ${ }^{120}$ While the eligibility criteria associated with some asset classes such as

\footnotetext{
${ }^{119}$ In general examples of "close links" arise in situations where the counterparty submits assets issued or guaranteed by itself or by an entity from within its corporate structure.

${ }^{120}$ At a minimum, the following eligibility criteria are important in the case of loans; consent of the borrower for the transfer of the loan, a defined level of arrears (which may well be zero), debtor income verification, a defined loan-to-value threshold, and the type of loan eligible (e.g., annuity loans only).
} 
securities is relatively straight forward to establish and asset variables remain relatively static, loans are not so straightforward particularly as the majority of variables are not publically available and also change in line with economic conditions.

\section{Risk tolerance}

Internally defined eligibility should be established ex ante. In many cases, a CB may be tempted to accept whatever assets are available to the counterparty no matter how illiquid they are and simply apply an arbitrary haircut to cater for unidentified risks. While a government indemnity for LOLR may provide some comfort to the $\mathrm{CB}$, from a good governance perspective, the Bank should nonetheless define eligibility criteria, which reduces the potential recourse to the indemnity. ${ }^{121}$ As mentioned earlier, such eligibility criteria should be defined in line with the CB's risk appetite, rather than being based on what collateral the counterparty is willing to mobilize.

Risk tolerance levels therefore define the main parameters of the CB's eligibility criteria. They essentially represent the amount of risk, on a broad level, "an organization is willing to take on in pursuit of value. Or in other words, the total impact of risk an organization is prepared to accept in the pursuit of its strategic objectives" which in the case of LOLR is said to be a financial stability objective. ${ }^{122}$ Through the development of risk tolerance levels the $\mathrm{CB}$ is trying to quantify the amount of risk a $\mathrm{CB}$ is going to accept in it's lending.

It is also important for the CB to keep in mind appropriate balance between the liquidity needs of the system and the risks on the CB's balance sheet. Moreover, there is often a tradeoff between imposing penal haircuts and therefore generating high asset encumbrance levels on financial institution balance sheet (which inhibits potential access to market sources of funding) and using lower haircuts (which give less protection to the $\mathrm{CB}$ ).

\section{Haircuts}

The use of a haircut gives the CB the strongest ability to recoup the public monies lent to a failed institution through the realization of the collateral. Specifically its purpose is to protect the CB's balance sheet against possible adverse changes in the market value of an asset before its liquidation, or a loss in value when selling an illiquid asset into a weak market. Based on the accepted risk tolerance level, CBs should aim to develop an appropriate haircut methodology, which at a minimum takes into account liquidity, credit, market, valuation, and

\footnotetext{
${ }^{121}$ For example, it would not be prudent to accept loans as collateral in cases where legal title cannot be transferred to the CB.

${ }^{122}$ See KPMG (2008) p.3.
} 
concentration risks. ${ }^{123}$ The fact that different assets present different market liquidity and credit characteristics makes it impossible to have a single haircut that can be applied across all asset classes. However, it is possible to have one single methodology.

The haircut applied by the CB should reflect the likely fact that the underlying asset will not, in normal circumstances, be realized and instead will be returned to the counterparty at a later date. However, this does not mean that the CB does not need to be adequately protected during the lifetime of the liquidity provision operation.

CBs often believe that before they accept any form of collateral, they must have sophisticated haircut and valuation frameworks in place. This is not necessarily the case. Depending on the operational expertise and the time, it is suggested that a CB take a two step approach to the development of an appropriate haircut and valuation methodology, adjusting its risk tolerance levels as necessary. While some CBs may just apply the same haircuts as those applied to their monetary policy lending or frameworks of other countries, possibly with a haircut 'addon' to cater for country specificities (Phase 1), other CBs may have a preference for more scientific approaches (Phase 2).

- $\quad$ Phase One-Conservative haircuts. The CB could mirror its haircut methodology on that of another CB that accepts similar assets, while also using an "add-on" to reflect the specificities of the local market, depending on the risk tolerance levels of the CB. For example, the ECB in its OMOs accepts a wide variety of collateral, from securities to loans, and the published haircut schedules ${ }^{124}$ could be adopted by a noneuro zone CB. The formulation of the percentage "add-on" in this phase does not have to be an exact science, but could reflect the inferior quality of the asset, or nonmarketability, or to cater for FX risk.

- $\quad$ Phase Two-Development of more advanced haircuts. In this instance, the CB relies on quantitative methods such as value-at-risk, requiring a considerable amount of market data in order to establish the liquidity characteristics and price volatility of the asset.

\section{Valuation}

The frequency of collateral valuation is an important factor in protecting the balance sheet of the $\mathrm{CB}$, where the $\mathrm{CB}$ should aim to value assets regularly at mark-to-market prices. The importance of frequent valuation is based on the presumption that the liquidation price loss

\footnotetext{
${ }^{123}$ Additional margin should be applied if other risks related to the underlying assets need to be considered in the valuation, such as legal and currency risks.

${ }^{124}$ See General Documentation on the Instruments and Procedures of the Eurosystem Monetary Policy, September 2011, ECB.
} 
(if such events arise) will be smaller if the assets are valued more recently (ideally daily). In general, the less frequent the valuation applied, the higher the haircut that should be applied to the asset. However, given the expected illiquidity of the collateral presented, valid market prices often do not exist, meaning other methods of valuation have to be found.

\section{Table 5. Central Bank Valuation Approaches}

\begin{tabular}{|c|l|c|}
\hline Step & \multicolumn{1}{|c|}{ Valuation Approach Preference } & Level of Sophistication \\
\hline 1 & $\begin{array}{l}\text { Apply the daily market price quoted on service providers } \\
\text { such as Bloomberg or Reuters. If there are doubts with } \\
\text { regard to the frequency of the prices (should not be stale } \\
\text { for more than five days as a rule of thumb) or liquidity in } \\
\text { the market, then: }\end{array}$ & Low \\
\hline 2 & $\begin{array}{l}\text { Apply a theoretical valuation, which is a complex } \\
\text { approach using future cash flows (including any call/put } \\
\text { options etc) discounted through the application of an } \\
\text { appropriate discount rate. This discount rate can be } \\
\text { formulated using data on market prices and credit } \\
\text { default swap levels and other data where available. } \\
\text { However, if a complete suite of data points, or reliable } \\
\text { data, or technical expertise is not available then: }\end{array}$ & High \\
\hline 3 & $\begin{array}{l}\text { Imply a price using techniques such as bootstrapping } \\
\text { using proxies for variables that are not available for the } \\
\text { security, such as swap rates. If there are no reliable } \\
\text { variables or proxies available then: }\end{array}$ & Moderate \\
\hline 4 & $\begin{array}{l}\text { Apply the face value less an estimated value for any } \\
\text { upcoming interest payments expected to be made } \\
\text { during the life of the LOLR operation, and then increase } \\
\text { the haircut by a sufficient amount. In the case of loan } \\
\text { collateral, this may be the CB's chosen valuation } \\
\text { approach should theoretical valuation (no. 2 above) not } \\
\text { be possible. }\end{array}$ & \\
\hline
\end{tabular}

Source: IMF Staff.

\section{Limits}

In order to avoid over exposure to the counterparty and/or collateral, and in the absence of a government indemnity, limits can be introduced by the CB.

\section{Borrowing limits}

Through the use of constructive ambiguity, some countries leave open the possibility for LOLR borrowing limits, while others have explicit limits in their legislation. ${ }^{125}$ As noted earlier, the preference should be to have internal limits from a risk control perspective, but in

\footnotetext{
${ }^{125}$ The Law on the Bulgarian National Bank stipulates that emergency loans can be extended "up to the amount of the excess of the lev equivalent of the gross international FX reserves over the total amount of monetary liabilities of the Bulgarian National Bank" (Article 33 (3)). See He (2000) for other examples of limits prescribed in legislation.
} 
the case of FX LOLR (where CB resources are more likely to be constrained) it may have to be disclosed that such support is limited (without having to publically disclose this limit). Regarding the general use of limits, some argue that the collateral available to an institution provides an implicit limit, but this is not strictly always the case, as sovereign guarantees (with a higher collateral value) can be used to collateralize operations should collateral be seriously impaired or is non transferable.

\section{Collateral limits}

Absolute or percentage limits can be introduced to prevent over exposure to particular collateral types. These would need to be regularly monitored and fall back solutions would need to be arranged (e.g., the provision of sovereign guarantees) when these limits might be breached.

\section{Haircut add-ons/valuation markdowns}

Haircut "add-ons" can be used to cater for the additional risk. This is normally the case when the collateral accepted is similar in all but a few features to existing assets for which haircuts have already been prescribed. For example, in the case of the Eurosystem, for its monetary policy operations, a haircut add-on is used in the case of certain assets that have all the characteristics of an ECB eligible security, except they are issued in certain non-euro currencies. In addition, the ECB applies a valuation markdown to certain self retained covered bond securities, to cater for possible double-default risk. While the difference in approaches is not immediately apparent, both essentially achieve the same result. ${ }^{126}$

\section{Due diligence requirements}

In the case of loan collateral, underlying data on loans mobilized as collateral is not generally available and therefore the $\mathrm{CB}$ has to rely on the counterparty for its provision. While the counterparty may "self certify" 127 the validity of these variables, it is nonetheless prudent for the $\mathrm{CB}$ to carry out checks on their provision in order to mitigate any potential conflicts of interest.

\footnotetext{
${ }^{126}$ The ECB publishes an Eligible Assets Database on a daily basis where the haircuts applicable to each potentially usable eligible asset are made public. One could argue that the application of valuation markdowns is easier to apply to self retained instruments as it simply means an adjustment to the theoretical valuation being applied to the asset at the time the asset is presented (the use of this valuation approach indicates a self retained issuance), rather than a technical update of the haircut where identification of those assets which are self retained is not clearly evident prior to their actual mobilization of the collateral.

${ }^{127}$ A letter should be submitted by the counterparty with each pool, signed by the head of treasury of equivalent, confirming the eligibility of each of the loans in the pool, along with confirming that the pool is in the agreed format.
} 


\section{Ex ante}

In instances where the potential need for LOLR is flagged well in advance, a number of ex ante due diligence checks should be performed by the operational and legal areas within the $\mathrm{CB} .{ }^{128}$ The purpose of on-site one-off ex ante verification checks is to ensure that the data is being correctly flagged on the counterparty's system, so as to avoid any risk of cross collateralization or the possibility of incorrect data sources being used. To carry out this check, the CB should understand how the variables for the loans are recorded on the bank's system and the source of these variables.

\section{Ex post}

The CB should ensure to the extent possible that the loans provided against the LOLR operation comply with the minimum eligibility criteria prescribed. ${ }^{129}$ In order to do this, the $\mathrm{CB}$ should conduct a series of checks/validations on the pools provided. Ex post checks should then be carried out by the $\mathrm{CB}$ regarding the existence and eligibility of the loans provided. At an operational level, the $\mathrm{CB}$, using a sample of loans provided, should cross check the accuracy of the variables provided against the data on the counterparty's systems, where original documentation may need to be also examined. In addition, the bank's legal team should assess the legal documentation of the sample so ensure that they are complete and that appropriate legal requirements have been fulfilled and the underlying security exists.

\footnotetext{
${ }^{128}$ In the case of an urgent idiosyncratic request, these checks can be completed ex post, but within a short timeframe.

${ }^{129}$ In some jurisdictions, given the nature of the regulatory regime such due diligence checks may not be necessary. For example New Zealand places greater emphasis on bank self-discipline and market discipline to provide incentives for prudent management, which it enforces through directors' attestations on their banks' risk management in public disclosures. See Reserve Bank of New Zealand: Bulletin, Vol. 67, No. 3.
} 


\section{Appendix IV. Minimizing Stigma-The Case of Open Market Operations}

Stigma concerns could potentially be reduced, where a number of banks are stressed, by providing liquidity via an OMO. ${ }^{130}$ This could involve expanding the collateral accepted in the monetary policy framework and satisfy the liquidity need through — in some instances longer term-OMOs, and using an interest rate higher than the policy target. ${ }^{131}$ This is somewhat related to the Goodfriend and King (1998) view mentioned earlier, but there is one importance difference, as in this instance the $\mathrm{CB}$ does not rely on the liquidity being distributed to 'concerned' banks, instead it is more likely that the required reserves provided will be bid for (only) by the institution(s) in need. In addition, it could be argued that its announcement could help with market confidence. Similar approaches (sometimes pre-emptive) were adopted during the GFC by the Reserve Bank of New Zealand, the Reserve Bank of Australia and, to a certain extent, the ECB. ${ }^{132}$ In many countries, even if counterparties have suitable monetary policy eligible collateral, there is at least an internal stigma associated with accessing standing facilities, as the performance of bank treasurers is sometimes measured on their usage of these facilities. ${ }^{133}$ The provision of (possibly longer term) OMOs against collateral that is normally reserved for standing facilities (if there is a separate collateral list) could mitigate this constraint. ${ }^{134}$

Careful consideration needs to be given to the design of any market-wide operation. Paul Tucker in BIS (2014) outlines that such solutions need constant innovation: if it is suspected that these facilities are being used to assist illiquid institutions, there is a risk that "sound" institutions may publically declare their intention not to use these facilities in the future. In the euro zone, a number of so-called "stronger" banks publically declared that they had repaid their three-year LTRO borrowings, implying that it was only 'stressed' institutions that remained in these operations. Any perceived stigma could potentially be managed through the use of moral suasion by the $\mathrm{CB}$, as was used recently by the BOE. ${ }^{135}$

${ }^{130}$ It is important to note that CBs should have clear principles behind when they will provide such liquidity support and should not change these principles as individual liquidity needs arise.

${ }^{131}$ Depending on the nature of demand, liquid securities instead of reserves could be provided.

${ }^{132}$ As mentioned earlier, in the case of the ECB, collateral constraints continued to impact peripheral banks even after the ECB expanded its collateral base. Moreover, through their LTROs, the ECB relied to an extent on counterparties distributing LTRO reserves to concerned counterparties, which did not happen in practice.

${ }^{133}$ Moreover, some monetary policy standing facilities are not automatic and may involve additional regulatory oversight, which is not recommended.

${ }^{134}$ For example, in the U.S. Federal Reserve's TAF operation, longer term liquidity was made available to a wider set of counterparties against a wider list of collateral normally reserved for the overnight discount window.

${ }^{135}$ Larger U.K. banks committed, after some moral suasion from the BoE, to drawdown on the Special Liquidity Scheme for a minimum amount and maintain at least that level of drawings for three years (Winters, 2012). 
The use of OMOs to meet market-wide needs during the GFC helped to reduce stigma over accessing CB liquidity. Announcing clear eligibility criteria and intended goals of the systemic operations, disclosure of access only with an appropriate time lag, and the nonapplicability of increased supervisory intrusion and conditionality, also provided the banking system with more comfort in terms of access. But by the same token, removing stigma from liquidity provided via OMO must increase the risk of stigma for bilateral LOLR. 


\section{REFERENCES}

Adler, G., P. Castro, and C. Tovar, 2012, "Does Central Bank Capital Matter for Monetary Policy?”, IMF Working Paper No. WP/12/60.

Bagehot, W., 1873, Lombard Street: A Description of the Money Market. E. Johnstone; Hartley Withers, eds. 1873. Library of Economics and Liberty. June 25, 2014, www.econlib.org/library/Bagehot/bagLom7.html.

Baring, Sir F., 1797, Observations on the Establishment of the Bank of England and on the Paper Circulation of the Country, London.

Bank for International Settlements, 2003, “The Role of Central Bank Money in Payment Systems", Committee on Payment and Settlement Systems.

Bank for International Settlements, 2014, "Re-thinking the Lender of Last Resort", BIS Papers No. 79.

Bank of Canada, 2004, "Bank of Canada Lender-of-Last-Resort Policies”, Financial System Review, www.bankofcanada.ca.

BCBS, 2013a, "Global Systemically Important Banks: Updated Assessment Methodology and the Higher Loss Absorbency Requirement", Basel Committee on Banking Supervision.

BCBS, 2013b, "Liquidity Stress Testing: a Survey of Theory, Empirics and Current Industry and Supervisory Practices", Basel Committee on Banking Supervision.

Begalle, B., A. Martin, J. McAndrews, and S. McLaughlin, 2013, "The Risk of Fire Sales in the Tri-Party Repo Market”, Federal Reserve Bank of New York, Staff Report No. 616.

Bindseil, U., and F. Papadia, 2009, "Risk Management and Market Impact of Central Bank Operations", Risk Management for Central Banks and Other Public Investors, Cambridge University Press.

Bindseil, U., 2014, Monetary Policy Operations and the Financial System, Oxford University Press.

Bollard, A., "Promoting Strong Corporate Governance in New Zealand Banks", Reserve Bank of New Zealand: Bulletin, Vol. 67, No. 3.

Brealey, R., A. Clark, J. Healey, G. Hoggarth, D.T. Llewwllyn, C. Shu, P. Sinclair, and F. Soussa, 2001, "Financial Stability and Central Banks A Global Perspective", Central Bank Governors' Symposium Series, Bank of England. 
Buiter, W., A.C. Sibert, 2007, “The Central Bank as the Market Maker of last Resort: From lender of last resort to market maker of last resort", www.voxeu.org.

Bulir, A., M. Cihak, and D-J. Jansen, 2014, "Does the Clarity of Inflation Reports Affect Volatility in Financial Markets?”, IMF Working Paper No. WP/14/175.

Calomiris, C., and U. Khan, 2015 "An Assessment of TARP Assistance to Financial Institutions, Journal of Economic Perspectives, Volume 29, Number 2.

Campbell, A., and R. Lastra, 2009, "Revisiting the Lender of Last Resort", Banking \& Finance Law Review 2008-2009, Thomson Reuters Canada.

Carney, M., 2013, "Speech as Part of the Financial Times 125th Anniversary Celebrations", London, www.bankofengland.co.uk.

Cebotari, A., 2008, “Contingent Liabilities: Issues and Practice”, IMF Working Paper No. $\mathrm{WP} / 08 / 245$.

CGFS, 2008, "Central bank Operations in Response to the Financial Turmoil”, Bank for International Settlements, Paper No 31.

CGFS, 2013, "Asset Encumbrance, Financial Reform and the Demand for Collateral Assets", Bank for International Settlements, Paper No. 49.

Corrigan, G. E., 2000, “Are Banks Special? A Revisitation”, www.minneapolisfed.org.

CPSS-IOSCO, 2012, "Principles for Financial Market Infrastructures”, Bank for International Settlements and International Organization of Securities Commissions, April.

Dudley, B., 2013, "Fixing Wholesale Funding to Build a More Stable Financial System”, Remarks at the New York Bankers Association's 2013 Annual Meeting \& Economic Forum, The Waldorf Astoria, New York City.

Del Mar Cacha, M., and R. A. Morales, 2003, “The Role of Supervisory Tools in Addressing Bank Borrowers' Currency Mismatches”, IMF Working Paper No. WP/03/219.

ECB, 2010, “ECB Signs Swap Facility Agreement with the Bank of England”, www.ecb.int.

ECB, 2013, "ELA Procedures", www.ecb.int.

ECB, 2014, "Experience with Foreign Currency Liquidity-providing Central Bank Swaps", ECB Monthly bulletin, August.

KPMG, 2008, “, “Understanding and Articulating Risk Appetite”, www.kpmg.com. 
Financial Stability Board, 2011, "The Key Attributes of Effective Resolution Regimes for Financial Institutions”, updated October 2014, Financial Stability Board.

Financial Stability Board, 2012, “OTC Derivatives Market Reforms: Third Progress Report on Implementation”, Financial Stability Board.

Financial Stability Board, 2014, "Guidance on Supervisory Interaction with Financial Institutions on Risk Culture - A Framework for Assessing Risk Culture”, April 7, 2014.

Freixas, X., C. Giannini, G. Hoggarth, and F. Soussa, 2000, "Lender of Last Resort: What Have We Learned Since Bagehot?", Journal of Financial Services Research.

Fontaine, J.S., J. Selody, and C. Wilkins, 2009, "Improving the Resilience of Core Funding Markets”, Financial System Review, Bank of Canada, December.

Goodfriend, M., and R.G. King, 1988, "Financial Deregulation, Monetary Policy, and Central Banking”, Federal Reserve Bank of Richmond, Working Paper No. 88-1.

Goodhart, C.A.E., 2010, “The Changing Role of Central Banks”, Bank for International Settlements, Working Paper No. 326.

Goodhart, C.A.E., 1999, "Myths about the Lender of Last Resort”, Financial Markets Group, London School of Economics, Special Paper 120.

Gray, S., and N. Talbot, 2006. “CCBS Handbook - Monetary Operations”, Centre for Central Banking Studies, Bank of England.

He, D., 2000, “Emergency Liquidity Support Facilities”, IMF Working Paper No 79.

Hoggarth, G., J. Reidhill, P. Sinclair, 2004, “On the Resolution of Banking Crises: Theory and Evidence", Bank of England, Working Paper no. 229.

Humphrey, T.M., 1975, “The Classical Concept of the Lender of Last Resort”, FRB Richmond Economic Review, Vol. 61, January/February 1975, pp. 2-9.

Humphrey, T.M., 1989, "Lender of Last Resort: The Concept in History", FRB Richmond Economic Review, March/April 1989, pp. 8-16.

IMF, 2011, "Sweden: Financial Sector Assessment Program Update-Technical Note on Contingency Planning, Crisis Management and Bank Resolution”, IMF Country Report No. 11/287. 
IMF, 2013, "European Union: Publication of Financial Sector Assessment Program Documentation-Technical Note on Deposit Insurance", IMF Country Report No. $13 / 66$.

IMF, 2014, "Austria: Publication of Financial Sector Assessment Program DocumentationTechnical Note on Crisis Preparedness and Management Framework", IMF Country Report No. 14/15.

IMF, 2015, “Assessing Reserve Adequacy_Specific Proposals”, April, http://www.imf.org/external/np/pp/eng/2014/121914.pdf.

Johnsen, G., 2014, Bringing Down the Banking System, Lessons from Iceland, Palgrave Macmillan, New York.

Johnson, G., and E. Santor, 2013, “Central Bank Liquidity Provision and Core Funding Markets", www.rba.gov.au.

Kohn, D.L., 2009, "Policy Challenges for the Federal Reserve", Speech at the Kellogg Distinguished Lecture Series, Kellogg School of Management, Illinois.

Laeven, L., and F. Valencia, 2012, "Systemic Banking Crises Database: An Update”, IMF Working Paper No. 12/163.

Laidler, D., 2002, "Two Views of the Lender of Last Resort: Thornton and Bagehot", University of Western Ontario, Research Report No 36.

Lavoie, S., A. Sebastian, and V. Traclet, 2011, "Lessons from the Use of Extraordinary Central Bank Liquidity Facilities”, Bank of Canada Spring Review.

Moe, T.G., 2012, "Shadow Banking and the Limits of Central Bank Liquidity Support: How to Achieve a Better Balance between Global and Official Liquidity", Levy Economics Institute, Working Paper No 712.

Nakaso, H., 2013, “Financial Crises and Central Banks' 'Lender of Last Resort' function", Remarks at Executive Forum, World Bank, Washington DC, and April 22, 2013.

Nyberg L., 2010, “The Infrastructure of Emergency Liquidity Assistance - What is Required in Today's Financial System?" Speech at the CGFS regional meeting in Tokyo, Bank of Japan, www.bis.org.

Plenderleith, I., 2012, "Review of the Bank of England's Provision of Emergency Liquidity Assistance in 2008-09", Presented to the Court of the Bank of England, www.bankofengland.co.uk. 
__, 2014, "UPDATE 1-Bulgarian Lawmakers Reject Debt Proposals for Bank Rescue", Reuters, July 17.

Psaroudakis, G., 2012, "State Aids, Central Banks and the Financial Crisis", European Company and Financial Law Review, Volume 9, Issue 2 (Jul 2012).

Reinhart, C., and K. Rogoff, 2013, "Financial and Sovereign Debt Crises: Some Lessons Learned and Those Forgotten", IMF Working Paper No. WP/13/266.

Reinhart, C., K. Rogoff, M. Savastano, 2014, “Addicted to Dollars”, Annals of Economics and Finance, 15 No. 1.

Singh, M., "Limiting Taxpayer "Puts"—An Example from Central Counterparties", IMF Working Paper No. WP/14/203.

Thornton, H., 1802, An Enquiry into the Nature and Effects of the Paper Credit of Great Britain, Edited with an Introduction by F. A. v. Hayek. New York: Rinehart \& Company, Inc., 1939.

Webel, B., 2013, "Troubled Asset Relief Program (TARP): Implementation and Status, Congressional Research Service", www.crs.gov.

Wendt, F., 2015, "Central Counterparties: Addressing their Too Important to Fail Nature", IMF Working Paper No. WP/15/21.

Winters, B., 2012, "Review of the Bank of England's Framework for Providing Liquidity to the Banking System", Presented to the Court of the Bank of England, www.bankofengland.co.uk.

Woo, D., 2000, "Two Approaches to Resolving Nonperforming Assets during Financial Crises", IMF Working Paper No. WP/00/33. 